\title{
Biography and Homoeopathy in Bengal: Colonial Lives of a European Heterodoxy ${ }^{1}$
}

\author{
Short Title: Biography and Homoeopathy in Bengal \\ Centre for Research in Arts Social Science and Humanities, \\ University of Cambridge, UK \\ Email: sd591@cam.ac.uk
}

\begin{abstract}
Despite being recognised as a significant literary mode in understanding the advent of modern self, biographies as a genre have received relatively less attention from South Asian historians. Likewise, histories of science and healing in British India have largely ignored the colonial trajectories of those sectarian, dissenting, supposedly pseudo-sciences and medical heterodoxies that flourished in Europe since the late eighteenth century. This article addresses these gaps in the historiography to identify biographies as a principal mode through which an incipient, 'heterodox' western science like homoeopathy could consolidate and sustain itself in Bengal. In recovering the cultural history of a category that the state archives render largely invisible, this article contends biographies as more than a mere repository of individual lives, and to be a veritable site of power. In bringing histories of print and publishing, histories of medicine and histories of life writing practices together, it pursues two broad themes: First, it analyses the sociocultural strategies and networks by which scientific doctrines and concepts are translated across cultural borders. It explores the relation between medical commerce, print capital and therapeutic knowledge, to illustrate that acculturation of medical science necessarily drew upon and reinforced local constellations of class, kinship and religion. Second, it simultaneously reflects upon the expanding genre of homoeopathic biographies published since the mid nineteenth century: on their features, relevance and functions, examining in particular, the contemporary status of biography vis-à-vis 'history' in writing objective pasts.
\end{abstract}

\section{Introduction}

'... some of the greatest men of India have had the shortest biographies. Many great men have been enwrapped in the folds of oblivion. ' '...there is very strong evidence that Bengal does not know its great men'. ${ }^{3}$

'As India entered the colonial era, the earlier hagiographical tradition was beginning to be supplemented, and to some extent supplanted, by a new form of biography, in which greater attention was given to complexity of character and personal motivation, to specific places and events, and to their role in shaping and explaining individual lives. ${ }^{4}$

In his three-part serialised biography of physician Rajendralal Dutta published in the monthly periodical The Hahnemannian Gleanings quoted above, the author repeatedly lamented Bengal's lack of appropriate engagement with the lives of its great men as compared to the standards set by the west. The lamentation of the biographer as well as the subsequent

\footnotetext{
${ }^{1}$ I thank the anonymous referees and the editorial team of Modern Asian Studies, along with Partha Chatterjee, David Arnold, Christopher Pinney, Jim Secord, Sanjoy Bhattacharya, Guy Attewell, Bodhisattva Kar, Shrimoy Roychaudhuri, Sukanya Sarbadhikary, Kate Nichols and Rohan Deb Roy for their comments on various drafts of this article.

${ }^{2}$ S.C.Ghose, (August 1932), 'Homoeopathy and Its First Missionary in India', The Hahnemannian Gleanings, 3 , 7, p. 289.

${ }^{3}$ S.C.Ghose, (November 1932), 'Homoeopathy and Its First Missionary in India', The Hahnemannian Gleanings, 3,10, p. 450.

${ }^{4}$ David Arnold and Stuart Blackburn (ed.) (2004), Telling Lives in India: Biography, Autobiography and Life

History, (Bloomington: Indiana University Press), pp. 8-9
} 
observation of historians studying 'life writing practices' ${ }^{5}$ in colonial India together hint at a proliferating culture of biographising lives through the nineteenth century. Over the last decade and a half, histories of colonial book, print and publishing have come to occupy an essential strand in analyses of South Asian modernity. ${ }^{6}$ These works, as well as those variously reflecting upon the advent of colonial modern subjectivities, have identified biography, along with autobiography, the novel, travel writing, diary and history as significant genres for the expression of an emerging modern self. ${ }^{7}$ In their analysis of the burgeoning print market in Bengal, arguably one of the most thriving colonial print markets, Anindita Ghosh and Tapti Roy suggest that although biographies comprised a fairly peripheral genre until the $1850 \mathrm{~s}$, there was a visible shift in the latter half of the nineteenth century. ${ }^{8}$ Indeed, following the nineteenth-century enumerations of Reverend James Long, Jatindramohan Bhattacharya and others, it is possible to trace the growing prominence of biography as a genre in the vernacular print market. Despite possible criticisms of such nineteenth century enumerations, men like Rev Long had statistically establish that since the 1850 s the 'tide turned in favour of more useful works' which among other categories, also included 'biographies of eminent men'.'

Of the myriad forms of writing lives, biography seems to have received relatively inadequate attention from South Asian scholars. By contrast, the world of autobiography and memoir, upheld as a direct site for recovering women and related minority voices, has been subjected to more regular historical scrutiny. ${ }^{10}$ In comparison, scholars have but rarely

\footnotetext{
${ }^{5}$ This is to collectively indicate the scholarship on writings of life including autobiography, memoir, biography, travelogue etc. Despite differences among scholars, it is generally agreed that the term 'life story' is preferable to 'life history' as the scope of the former is considered more comprehensive, with no explicit truth claim attached to it. See James Peacock and Dorothy Holland (1993), 'The Narrated Self: Life Stories in Process', Ethos, 21, 4, 367-368. Also see, David Arnold and Stuart Blackburn (ed.), Telling Lives in India, pp. 9-11 ${ }^{6}$ A few representative examples include Francesca Orsini (2002), The Hindi Public Sphere, 1920-1940: Language and Literature in the Age of Nationalism, (New York: Oxford University Press), Vasudha Dalmia and Stuart Blackburn (ed) (2004), India's Literary History: Essays on the Nineteenth century, (Delhi: Permanent Black), Abhijit Gupta and Swapan Chakravarty (ed) (2004), Print Areas: Book History in India, (Delhi: Permanent Black), A R Venkatachalapathy (2012), The Province of the Book: Scholars, Scribes, and Scribblers in Colonial Tamilnadu, (Delhi: Permanent Black), Farina Mir (2010), Social Space of Language: Vernacular Culture in British Colonial Punjab, (Berkeley: University of California Press)

${ }^{7}$ Dipesh Chakrabarty (2000), Provincialising Europe: Postcolonial Thought and Historical Difference, (New Jersey: Princeton University Press), pp. 34-35 and Javed Majeed (2007), Autobiography, Travel and Postnational Identity: Gandhi, Nehru and Iqbal, (Basingstoke: Palgrave Macmillan). Also see Bhaskar Mukhopadhyay (2002), 'Writing Home, Writing Travel: Poetics and Politics of Dwelling', Comparative Studies in Society and History, 44, 2, p. 298. Apart from biography, history, and novel Mukhopadhyay includes 'diary-writing' as well as 'travel writing' as other modes of modern self-expression.
}

\footnotetext{
${ }^{8}$ See Anindita Ghosh (2006), Power in Print: Popular Publishing and the Politics of Language and Culture in a colonial Society, ( Delhi: Oxford University Press), pp. 131-133 and Tapti Roy (1995), 'Disciplining the Printed Text: Colonial and Nationalist Surveillance of Bengali Literature', in Partha Chatterjee (ed.) Texts of Power: Emerging Disciplines in Colonial Bengal, (Minneapolis : University of Minnesota Press), pp. 38-41

${ }^{9}$ Ibid, pp. 38

${ }^{10}$ For some examples of the use of autobiography or memoir as an analytic tool in understanding gender and patriarchy and/or caste see Tanika Sarkar (1995), 'A book of her Own, A life of Her Own : Autobiography of a Nineteenth Century Woman', History Workshop, 36, pp. 35-65; Partha Chatterjee (1993), 'Women and the Nation', The Nation and its Fragments: Colonial and Postcolonial Histories, (New Jersey: Princeton University Press), pp. 135-157, Sharmila Rege (2006), Writing Caste, Writing Gender: Reading Dalit Women's Testimonios, (Delhi: Zuban), Meenakshi Mukherjee (1988), 'The Unperceived Self: A Study of Five Nineteenth century Autobiographies' in Karuna Chanana (ed.) Socialisation, Education and Women: Explorations in Gender Identity, (Delhi: Orient Longman), 1988, Geraldine Forbes and Tapan Raychaudhuri (ed.) (2000), The Memoirs of Dr. Haimabati Sen, from Child Widow to Lady doctor, (Delhi: Roli Books), Antoinette Burton (2000), 'The Purdahnashin in her setting: Colonial Modernity and the Zenana in Cornelia Sorabji's Memoirs', Feminist Review, 65, pp 145-158. For other kinds of exploration around autobiography see Brian Hatcher
} 
engaged with biographies on their own terms. While biographies typically have been instrumentalised as sources for other kinds of histories, South Asian historians have particularly been more inclined in the critical historical-biographic recreation of renowned lives, most evidently the prominent leaders of our imperial and colonial pasts including Clive, Bentinck, Nehru, Gandhi and others. ${ }^{11}$ Since the 1990s, a growing distrust for metanarratives has further resulted in a new kind of fascinating individual oriented work that has focussed on bringing to life lesser known figures of more humble backgrounds. ${ }^{12}$ Some of these very interesting histories have been informed by the microhistorical approach. ${ }^{13}$ Indulging in a strictly person-centred narrative, these scholars have frequently demonstrated the archival fragments of individual lives to be an extraordinary window to the larger social milieu that their subjects inhabited. ${ }^{14}$ In the process, to narrate their histories, they have, in some cases, reified what Bourdieu has famously termed as 'the biographical illusion' i.e. the teleological continuities of a coherent life. ${ }^{15}$ In sum, whether consciously or not, and with varying degrees of criticality, these historians have sometimes tended to assume for themselves the role akin to a life narrator, deploying facets of individual life history as a methodology for narrating larger histories of South Asia. ${ }^{16}$

(2001), 'Sanskrit Pandits Recall their Youth: Two Autobiographies from Nineteenth century Bengal', Journal of the American Oriental Society, 121, 4, pp. 580-592, Sudipta Kaviraj (2004), 'The Invention of Private Life: A reading of Shibnath Shastri's Autobiography', in David Arnold and Stuart Blackburn (ed.) Telling Lives in India, pp. 83-115, Uday Kumar (2008), 'Autobiography as a Way of Writing History: Personal Narratives from Kerala and the Inhabitation of Modernity', in Partha Chatterjee and Raziuddin Aquil (eds.), History in the Vernacular, (Delhi: Permanent Black)

${ }^{11}$ There is a long established scholarly tradition of political biographies by historians of imperialism. For some earlier representative examples see Percival Spear (1975), Master of Bengal: Clive and his India, (Thames and Hudson), John Rosselli (1974), Lord William Bentinck: Making of a Liberal Imperialist, 1774-1839, (Berkeley and Los Angeles: University of California Press), Burton Stein (1989), Thomas Munro: the Origins of the Colonial State and his Vision of Empire, (Delhi: Oxford University Press), Lynn Zastoupil (1994), John Start Mill and India, (Stanford: Stanford University Press). For more recent critical historical explorations of the lives and thoughts of major nationalist figures see B R Nanda (1998), Three Statesmen: Gokhale, Gandhi and Nehru, (New Delhi and Oxford: Oxford University Press), Judith M Brown (2003), Jawaharlal Nehru: A political Life, (New Haven: Yale University Press), Benjamin Zachariah (2004), Nehru, (London, New York: Routledge), Stanley Wolpert (2001), Gandhi's Passion: Life and Legacy of Mahatma Gandhi, (Oxford: Oxford University Press), Sugata Bose (2011), His Majesty's Opponents: Subhas Chandra Bose and India's Struggle against Empire, (Cambridge: Harvard University Press)

${ }^{12}$ For some recent explorations see Richard Eaton (2005), Social history of Deccan, 1300-1761: Eight Indian Lives, (Cambridge: Cambridge University Press), Gloria Goodwin Raheja (1994), Listen to the Heron's Words: Reimagining Gender and Kinship in North India, (University of California Press), Gautam Bhadra (1988), 'Four Rebels of Eighteen Fifty-Seven', in Ranajit Guha and Gayatri Spivak (ed), Selected Subaltern Studies, (Delhi: Oxford University Press), pp. 129-178, Clare Anderson (2012), Subaltern Lives: Biographies of Colonialism in the Indian Ocean World, 1790-1920, (Cambridge: Cambridge University Press)

${ }^{13}$ For a relation between microhistory and biography see Jill Lepore (2001), 'Historians Who Love Too Much: Reflections on Microhistory and Biography', Journal of American History, 88, 1, pp. 129-144

${ }^{14}$ For a recent exploration on the current relation between biography and History see AHR Roundtable Special Isuues, 'Historians and Biography', American Historical Review, 114, 3, June 2009. Also see the special issue 'Biography and History: Inextricably Interwoven', Journal of Interdisciplinary history, 40, 3, Winter 2010. Specially see Stanley Wolpert (2010), 'Biography as History: A personal Reflection', pp.399-412. A recent volume exploring similar questions is Vijaya Ramaswamy and Yogesh Sharma (ed.) (2009), Biography as History: Indian Perspectives, (Hyderabad: Orient Blackswan)

15 Pierre Bourdieu (2000), 'The Biographical Illusion', in Paul du Gay, Jessica Evan and Peter Redman (ed.), Identity: A Reader, (London: Sage Publications), pp. 299-305

${ }^{16}$ Of course, individual centric, micro historical studies need to be distinguished from the specialisation of 'intellectual history', which while engaging in individual- centric analysis essentially deals with the ideas and intellectual trajectories of major thinkers. 
Fascinating as these approaches are, what has remained relatively underexplored within this corpus is a reflection on biography itself as a specific form of historical document, its function and relevance as also the politics of its production beyond the narration of a single life. In a recent anthology on life writing practices, the editors usefully raise the point that historians in South Asia have seldom 'paused to consider them (life histories) as genres worthy of systemic analysis.' This is indeed more true of biography than any other genre. This paper redresses this gap in the scholarship by looking into the commercial as well as moral impulses behind the sustained publication of biographies by the adherents of a specific medical ideology. Rather than focussing on any individual life we would explore biography as a mode of expression for groups, sects or cults often considered marginalised. Narration of religious lives, often in the form of hagiographies, are increasingly of interest to scholars studying manoeuvres of sacred communities. ${ }^{17}$ This article, likewise, studies the content and function of the plethora of physicians' biographies with relation to the incipient, heterodox science ${ }^{18}$ of homoeopathy in Bengal. In so doing, it essentially interrogates the power of print capital in shaping and sustaining unorthodox, apparently marginal practices, not directly endorsed by the state.

Indeed, colonial trajectories of so-called European pseudo-sciences as well as medical heterodoxies like phrenology, magnetism, mesmerism, herbalism, hydropathy, homoeopathy, naturopathy or Christian Science have but rarely featured in histories of British India. ${ }^{19}$ Predictably, their (often self-proclaimed) status as heterodoxy and the mutating relationship with the mainstream, state-endorsed practices in Europe, have for long been the staple of a wide-ranging Anglo-American scholarship. ${ }^{20}$ Historiographical attention in South Asia, however, has remained overwhelmingly divided between studying aspects of state medicine promoted by the British government on the one hand, and that of the indigenous medico-

\footnotetext{
${ }^{17}$ See Tony K Stewart (1994), 'One Text from Many: Caitanya Caritamrita as 'Classic and Commentary' in Wianad Callewaert and Rupert Snell (ed.), According to Tradition: Hagiographical writing in India, Harrasowitz Verlag Wiesbaden , pp. 231-248 and Uday Kumar (2009), 'Writing the Life of the Guru, Chattampi Swamikal, Sree Narayan Guru and modes of Biographical construction', in Vijaya Ramaswamy and Yogesh Sharma (ed.) Biography as History: Indian Perspectives, (Hyderabad: Orient Blackswan), pp. 53-87. Andrew Quintman (2013), Yogin and the Madman: Reading the Biographical Corpus of Tibet's Great Saint Milarepa, (New York: Columbia University Press)

${ }^{18}$ The paper refers interchangeably to homoeopathy as both 'science' and 'medicine' as it was often perceived and championed in Bengal as a new scientific therapeutic from the west. For a historiographic overview of the complex relation between history of medicine and history of science that throw light on the evolving understanding and connotations of 'science' with regards to 'medicine' see John Harley Warner (1995), 'History of Science and Sciences of Medicine', Osiris, 10, pp. 164-193.

${ }^{19}$ For an interesting account of mesmerism in British India see Alison Winter (2000), 'Colonizing Sensations in Victorian India', in Mesmerized: Powers of Mind in Victorian Britain, (Chicago: University of Chicago Press), pp. 187-212. Also see Waltraud Ernst (2004), 'Colonial Psychiatry, Magic and Religion: The Case of Mesmerism in British India', History of Psychiatry, 15, 1, pp. 57-68. For accounts of naturopathy and Hydrotherapy as also Christian healing respectively see Joseph Alter (2000), Gandhi's Body: Sex, Diet and Politics of Nationalism, (Philadelphia: University of Pennsylvania Press), pp. 55-82 and David Hardiman (2012), 'A Subaltern Christianity: Faith Healing in southern Gujrat', in David Hardiman and Projit Mukharji (ed), Medical Marginality in South Asia: Situating Subaltern Therapeutics, (New York: Routledge), pp. 126151.

${ }^{20}$ For a classic study of questions of orthodoxy and heterodoxy in Victorian medicine see W.F.Bynum and Roy Porter (ed.) (1987), Medical Fringe and Medical Orthodoxy 1750-1850, (London and Wolfeboro, N.H.: Croom Helm) . Also see Roger Cooter (ed.) (1988), Studies in the History of Alternative Medicine, (New York: St Martin's Press), pp. x-xvii. For a survey of the ways in which orthodoxy and heterodoxy were key operative terms in not only Victorian medical world, but equally in Victorian sciences see Alison Winter (1997), 'The Construction of Orthodoxies and Heterodoxies in Early Victorian Life Sciences' in Bernard Lightman (ed), Victorian Science in Context, (Chicago: University of Chicago Press), pp. 24-50
} 
scientific traditions like ayurveda, unani and siddha on the other. Only recently has there been a turn of interest among historians towards studying the more esoteric, popular/folk, noncanonised therapeutic practices as bone-setting, faith healing and the like. ${ }^{21}$ Consequently, histories of health and healing in British India have largely ignored those motley sectarian, dissenting medical ideologies that flourished in Europe since the late eighteenth century, whose scientific status was hotly debated in western societies through the nineteenth century. While at least two of these heterodoxies, namely homoeopathy and naturopathy, along with ayurveda, yoga, unani and sidhha, is today part of the Government of India department of AYUSH that oversees the development of various forms of 'indigenous medicine', there has been a proclivity among historians in conflating their rich and divergent colonial pasts with that of histories of 'traditional' medicine. ${ }^{22}$ Sporadic works including Joseph Alter's insightful discussion on German naturopathy and hydropathy in India with relation to Gandhian corporeal practices, Alison Winter's intriguing work on the reception of mesmerism as eastern magic, or David Hardiman's study of Christian Science among tribals in southern Gujarat, hint at a fascinating cultural history of these heterodoxies hitherto uncharted.

It is true, however, that despite distinct ancestries, the imperial careers of European heterodoxies intersected, even converged with those of indigenous South Asian medicine at various moments, most prominently in sharing the brunt of the colonial state's discriminatory stance against them in favour of 'scientific' medicine. After an initial phase of attempts at syncretism with the indigenous medical cultures till about $1850 \mathrm{~s},{ }^{23}$ the British government indulged in an extended phase of public health policies that all but delegitimised traditional therapeutics as also any other up-and-coming unorthodox practice as homoeopathy. While existing scholarship has variously noted the beginnings of official tolerance for indigenous medicine around the First World $\mathrm{War}^{24}$, more recent works identify the dyarchic system of governance initiated in 1919 as a key moment that signalled a slow policy transition towards accepting as well as standardising non-biomedical practices. ${ }^{25}$

Consequently, spanning the latter half of the nineteenth and the first quarter of the twentieth century, heterodox practices such as homoeopathy (along with traditional indigenous medicine) were routinely curbed by the colonial state in Bengal, as elsewhere in South Asia. The state endorsed apparatus of western medicine, including the Calcutta Medical College as well as the appointments in the Indian Medical Service, were meticulous in excluding practitioners associated with homoeopathy from their ambit. The circumstances around the public embracing of homoeopathy by leading physicians as Mahendralal Sircar in 1867 , is a case in point. ${ }^{26}$ The furore surrounding the expulsion of Sircar, a physician of

\footnotetext{
${ }^{21}$ For a historical study of varieties of non-canonised practices see David Hardiman and Projit Mukharji (ed) (2012), Medical Marginality in South Asia: Situating Subaltern Therapeutics, (New York: Routledge). Medical anthropologists have predictably done more work in this direction, for instance, see William Sax (2009), God of Justice: ritual healing in the central Himalaya, (New York: Oxford University Press).

${ }^{22}$ See for instance the taxonomy of medical practices delineated in 'Agenda' in David Hardiman and Projit Mukharji (ed), Medical Marginality in South Asia, pp. 2-3, 7.

${ }^{23}$ For efforts at supposed harmony and syncretism see Zhaleh Khaleeli (2001), 'Harmony or Hegemony? The Rise and Fall of the Native Medical Institution, Calcutta; 1822-35,' South Asia Research, 21, pp. 77-104.

${ }^{24}$ See for instance Mark Harrison (1994), Public Health in British India: Anglo India Preventive Medicine 18591914, (Cambridge: Cambridge University Press), pp. 166-200

${ }^{25}$ Rachel Berger (2013), Ayuveda Made Modern: Political Histories of Indigenous Medicine, 1900-1955,

(Basingstoke: Palgrave Macmillan), pp. 2-4

${ }^{26}$ For a comprehensive account of Mahendralal's pioneering role in the development of science and medicine in India see Pratik Chakrabarty (2001), 'Science, Morality and Nationalism: the Multifaceted project of Mahendralal Sircar', Studies in History, 17, 2, pp. 245-274. Mahendralal's public 'conversion' to homoeopathy in 1867 was reported widely in contemporary newspapers and generated widespread public interest. For a compilation of such
} 
highest repute and the second M.D. of the Calcutta Medical College, from the medical faculty of the Calcutta University in 1878 on grounds of his being a homoeopath, constituted a highpoint in the scaling governmental intolerance towards any supposedly unorthodox practice. ${ }^{27}$ With a pronounced agenda of promoting 'orthodox' western medicine, leading journals like the Indian Medical Gazette acting as the quasi-official mouthpiece of the Indian Medical Service, celebrated Sircar's expulsion as the most appropriate step in 'maintaining the cause of scientific truth and purity in Bengal, unflinchingly against the faintest encouragement of or association with delusion or error. ${ }^{28}$ Indeed, the state remained attentive in policing homoeopathy, the latter figuring most prominently in bureaucratic anxieties related to medical malpractice in the province, particularly in governmental discussions on 'quackery' and 'corruption'. The Bengal Medical Bill of 1913 had introduced a medical council and a system of registration that, in effect, declared all practitioners of unorthodox medicine as illegal. It was followed by the passing of the Indian Medical (Bogus Degrees) Act 1915 that made it 'pretty evident that while tolerated, the other medical traditions would not be privileged or even considered part of the scientific tradition. ${ }^{29}$

Yet, this is not to stoke any romantic illusion of an uncontaminated 'outside' beyond the regimes of the state, with relation to these unorthodox practices. Even while being castigated by the state and the mainstream British scientific authorities in India, these practices were nonetheless sustained by institutions and processes shaped by colonial modernity, if not the colonial state. In case of homoeopathy in Bengal, these were the reformulated colonial family and more importantly, modern print culture. ${ }^{30} \mathrm{We}$ will particularly explore the agency of print culture (in collusion with the institution of family, as we will see), and indeed an exclusive genre of print as biography, in crystallising homoeopathy. Indeed, one could only get highly sketchy, disorderly yet suggestive glimpses of homoeopathy's flourishing sociocultural past from the official state archives. In recovering the cultural history of a category that the state archives renders largely invisible, this article contends biographies as more than a mere repository of straightforward information on individual lives, but to be a veritable site of power. Moreover, in pursuing the entangled histories of biography, family and homoeopathy in Bengal we hope to broaden our understandings of the modalities through

\footnotetext{
reports see Mahendralal Sircar (1903), On the Supposed Uncertainty in Medical Science and on the Relation between Diseases and their Remedial Agents, (Calcutta: Anglo Sanskrit Press), pp.62- 67

${ }^{27}$ For a detailed discussion of the expulsion see Arun Kumar Biswas (2003), Collected Works of Mahendralal Sircar, Eugene Lafont and the Science Movement, 1860-1910, (Kolkata: Asiatic Society), pp. 231-247

${ }_{28}$ Anonymous (June 1878), 'Homoeopathy and the University of Calcutta', Indian Medical Gazette, 13, p. 159

${ }^{29}$ See the discussion of the Medical Bills in Rachel Berger (2008), 'Ayurveda and the Making of the Urban Middle Class in North India 1900-1945', in Dagmar Wujastyk and Frederick Smith (ed. ), Modern and global Ayurveda: Pluralism and Paradigms, (Albany: SUNY Press), pp. 103-104

30 A recent spate of research on the institution of South Asian family and law unravel the ways in which the family as an institution was deeply controlled by the colonial state. Of particular relevance is Ritu Birla's work on colonial legislations and the Marwari family-firm, since the homoeopathic commerce was significantly reliant on the family firm model. See Ritu Birla (2009), Stages of Capital: Law, Culture and Market Governance in Late Colonial India, (Durham: Duke University Press). Likewise, mechanisms of surveillance of the print market by the state has been pointed out by a number of south Asian scholars including Tapti Roy, 'Disciplining the Printed Text: Colonial and Nationalist Surveillance of Bengali Literature', pp. 30-61 and Farina Mir, Social Space of Language: Vernacular Culture in British Colonial Punjab.
} 
which heterodox sciences consolidated in dispersed colonial societies as in Tibet, Japan, Transval or in Egypt. ${ }^{31}$

At one level, in making sense of the sustained deployment of the biographic mode by practitioners of homoeopathy, the article underlines the importance of expanding the historical query from the texts towards interrogating the imperatives of their publication. It identifies a range of intergenerational family-firms invested in homoeopathic print and commerce to argue biographies to be as much the story of the biographised as of the biographer and his publisher. ${ }^{32}$ It contends that biographies, in whatever form they are produced, are anything but innocent from a scholarly perspective. The interests of a range of physician-entrepreneurs operating through family-firms in publishing life stories, is considered crucial in understanding the institutions and networks that sustained colonial heterodoxies like homoeopathy. Consequently, the biographies publicised the image of Bengali homoeopathy as a family-oriented practice, perpetrated primarily by a number of key entrepreneurial families united in their shared vision of promoting radical cure for physical, social and moral ills. In so doing, the paper remains particularly attentive in exploring the role of biography in translating and vernacularizing German homoeopathy as not merely a familial science for Indian domesticity but also one ideally suited to a (Hindu) nationalist sensibility. Moreover, taking cue from the late nineteenth- early twentieth century biographers' proclamations of chronicling 'history' through individual lives, we will explore a Bengali public discourse around writing pasts. The homoeopathic projection of biography as a kind of history that valued 'intimacy' over 'objectivity' throws light on competing notions of history amongst sections of the colonial intelligentsia. It unravels the hesitations, among sections of Bengali biographers, with regards to the plausibility of western notions of objective history.

In sum, in its focus not only on print culture in general but on a distinct literary genre, the article extends the scholarship on the processes of localisation as well as sustenance of nonconformist practices in colonial societies. It explores how acculturation of European medicine and print capitalism necessarily drew upon and reinforced local constellations of religions, class, kinship and other networks of familiarities to unravel the nature of scientific modernity in South Asia. ${ }^{33}$ The article further makes a contribution to histories of life writing

\footnotetext{
${ }^{31} \mathrm{~A}$ range of work have initiated interesting conversations about unorthodox, marginal, often state censored medico-scientific practices with various forms of print networks. See Vincenne Adams (2001), 'The Sacred in the Scientific: Ambiguous Practices of Science in Tibetan Medicine', Cultural Anthropology, 16, 1, pp. 542575, Akiko Ito (2011), 'How Electricity Energizes the Body: Electrotherapeutics and its Analogy of Life in Japanese Medical Context' in Dhruv Raina and Feza Gunergun (ed.), Science between Europe and Asia, Historical Studies on the Transmission, Adoption and Adaptation of Knowledge, Springer, pp. 245-258, Joel Cabrita (Forthcoming 2015), ' People of Adam: Divine Healing and Racial Cosmopolitanism in the Early Twentieth-Century Transvaal, South Africa', Comparative Studies in Society and History, Marwa Elshakry (2013), Reading Darwin in Arabic, 1860-1950, (Chicago: University of Chicago Press).

${ }^{32}$ Recent studies in religious lives have begun being especially sensitive to the role of the biographer. See Kumkum Roy (2009), 'The Artful Biographer, Sandhyakar Nandi’s Ramcaritam', in Vijaya Ramaswamy and Yogesh Sharma (ed.) Biography as History: Indian Perspectives, pp. 17-29

${ }^{33}$ For a discussion of the ways in which colonial science and medicine thrives upon local power hierarchies and dominant class, caste and other prejudices see Gyan Prakash (Autumn 1992), 'Science Gone 'Native' in Colonial India', Representations, 40, Special Issue: Seeing Science, pp. 153-178. Also see, Padma Prakash (2005), 'Where is the Woman in Preventive and Social Medicine'? Economic and Political Weekly, 40, 18, p. 1828.
} 
in reflecting on the function and relevance of biography, on the nature of selfhood reified through biographies, as well as by examining late nineteenth century status of biography visà-vis history. Through a study of the relationship between biographer, subject of biography and modernity, it contends that apart from being instructive on larger questions of scientific modernity and the individual self, biographies also acts as sites to understand more immediate and mundane working of power in forging group identities.

\section{Print Cultures, Heterodox Sciences and a 'Biography Industry'}

Over the last few years, the historiography of science has come to focus more and more on what has been characterised as the new 'geographies of nineteenth century science ${ }^{34}$, sites and experiences beyond the laboratories, clinics or other conventional spaces associated with science. Along with museums, public lectures, galleries of practical science, panoramic shows, exhibitions etc, the role of the print market, especially the popular market around print, science, social and individual health has been explored in its various facets in the context especially of Victorian science. ${ }^{35}$ The sciences contested by the state and other related established authorities were crucially reliant on an increasingly global print network as James Bradley's work on British hydrotherapy or John Kucich's exploration of American spiritualism illustrate. ${ }^{36}$

The power of print, along with these other sites, in 'staging (colonial) science' is gradually being acknowledged in histories of South Asian science. Especially in case of medicine, the paradigm of 'medical markets' has emerged as an important analytic tool to understand the cultural life of colonial medicine where the 'marketplace of print' is of increasing importance as a concept. ${ }^{37}$ Indeed, a recent spate of fresh research on unorthodox health and physical cultures from colonial Hyderabad, Punjab, United Province and other parts of north India and Bengal, has opened up conversations about the rapidly growing popular print productions owing to fast changing technologies and the widening horizon of nineteenth-century reading and consuming public. ${ }^{38}$ These works, focusing on facets of traditional knowledge notes that the negotiation with modern print impacted upon customary practices with changing notions of authority, pupillage and consumption.

\footnotetext{
${ }^{34}$ David Livingstone and Charles Withers (ed.) (2011), Geographies of Nineteenth century Science, (Chicago: University of Chicago Press).

${ }^{35}$ See Jonathan Topham (2007), 'Publishing "Popular Science" in Early Nineteenth-Century Britain' in Aileen Fyfe and Bernard Lightman (ed), Science in the Marketplace: Nineteenth century Sites and Experiences,

(Chicago: Chicago University Press), pp. 135-68 and Jonathan Topham (2000), 'Scientific publishing and the Reading of Science in Nineteenth-century Britain: a Historiographical Survey and Guide to Sources', Studies in History and Philosophy of Science , Part A, 31 , 4, pp. 559-612.

${ }^{36}$ James Bradley (2002), 'Medicine on the Margins: Hydropathy and Orthodoxy in Britain, 1840-1860' in Waltraud Ernst (ed.), Plural Medicine, Tradition and Modernity, 1800-2000, (London and New York: Routledge), p. 34 and John Kucich (2004), Ghostly communion, Cross-cultural Spiritualism in the nineteenth century, (UPNE)). See the chapter 'Public spirits: spiritualism in American periodicals', pp. 36-58

${ }^{37}$ See Mark Jenner and Patrick Wallis (ed) (2007), Medicine and the Market in England and its Colonies, (Basingstoke: Palgrave Macmillan).

${ }^{38}$ Guy Attewell (2007), Refiguring Unani Tibb: Plural Healing in Late Colonial India, (New Delhi: Orient Longman), pp. 238-270; Kavita Sivaramakrishnan (2006), Old Potions, New Bottles: Recasting Indigenous Medicine in Colonial Punjab, 1850-1945, (Hyderabad: Orient Longman), pp. 104-157; Rachel Berger (2013), Ayuveda Made Modern, pp. 75-105; Charu Gupta (2001), Sexuality, Obscenity, and Community: Women, Muslims and the Hindu Public in Colonial India, (Delhi: Permanent Black), pp. 30-65; Projit Bihari Mukharji (2009), Nationalizing the Body: The Medical Market, Print and Daktari Medicine, ( London, New York, Delhi: Anthem Press), pp.75-110
} 
Drawing upon this existing scholarship, it is perhaps incumbent now to go beyond the idea of a monolithic print market to explore the various genres and formats of medicoscientific print. As the historiography of the book and reading argue, studying the specific formats and genre conventions in the print market is highly instructive of the ideas they seek to convey. ${ }^{39}$ While there has been some sporadic work on the function of science text books ${ }^{40}$ as also the didactic manuals on health ${ }^{41}$, periodicals have received the most lingering attention from historians of science in South Asia and beyond as a main conduit for forging knowledge and opinion in the nineteenth century. Focussing on various aspects as the 'periodicity' ${ }^{42}$ or the formation of a 'common (national) intellectual context' ${ }^{\text {' }}$ the role of periodicals has been identified as fundamental. ${ }^{44}$ While more recent South Asian works are branching out towards deciphering medical advertisements ${ }^{45}$, myriad other areas remains to be explored, not least the world of commercially printed science visuals that is increasingly being highlighted as yet another important site for the study of Victorian science and medicine. ${ }^{46}$

Furthering such historiographical trends, this article focuses on the writing and publication of medical biographies. While acknowledging biography to be an important mode in narrating science especially since the 1960s, historians of science have debated the usefulness of biography as a means of doing history of science, mostly agreeing that 'biography, however useful, exerts a powerfully distorting image of how most science gets done. ${ }^{47}$ Few works other than the important collection of essays by Michael Shortland and Richard Yeo, however, actually delve into the writings and circulation of nineteenth century medico-scientific biographies and their impact. ${ }^{48}$ This paper precisely does that. An exploration into the depths of popular medical print culture in Bengal overwhelms one with the regularity with which biographies of homoeopathic practitioners were published from the latter half of the nineteenth century. These ranged from eulogising accounts of Hahnemann,

\footnotetext{
${ }^{39}$ For a couple of authoritative studies see Robert Darnton (1987), The Business of Enlightenment: A publishing History of the Encyplopaedia, 1775-1800, (Cambridge: Harvard University Press), and William St Claire (2004), The Reading Nation in the Romantic Period, (Cambridge: Cambridge University Press).

${ }^{40}$ Dhruv Raina and S. Irfan Habib (1990), 'Ramchandra's Treatise through the 'Haze of the Golden Sunset': An aborted Pedagogy', Social Studies of Science, 20, 3, pp. 455-472

${ }^{41}$ Rohan Deb Roy (2011), 'Debility, Diet, Desire: Food in Nineteenth and Early Twentieth Century Bengali Manuals' in Supriya Chaudhari and Rimi B Chatterjee (ed) The Writer's Feast :Food and the Cultures of Representation, (Hyderabad: Orient Blackswan ) pp.179-205,

42 James Wald (2009), 'Periodicals and Periodicity' in Simon Eliot and Jonathan Rose (ed), A companion to the History of Book, (Oxford: Wiley Blacwell), pp. 421-432
}

${ }^{43}$ Geoffrey Cantor et al (ed.) (2004), Science in the Nineteenth-Century Periodical: Reading the Magazine of Nature, (Cambridge: Cambridge University Press).

${ }^{44}$ For explorations in the study of the importance of periodicals in the Indian context see Amit Ranjan Basu (2004), 'Emergence of a marginal Science in a Colonial City: Reading Psychiatry in Bengali Periodicals', Indian Economic and Social History Review, 41, 2, pp. 103-141 Also see Projit Mukhari, Nationalising the Body, pp. 92-100. For a recent study of literary periodicals and its readership in Bengal see Samarpita Mitra (2013), 'Periodical Readership in Early Twentieth Century Bengal: Ramananda Chattopadhyay's Prabasi', Modern Asian Studies, 47, 1, pp:204-249

${ }^{45}$ Madhuri Sharma (2009), 'Creating a consumer: Exploring Medical Advertisements in Colonial India' in Mark Harrison and Biswamoy Pati (ed.), The Social History of Health and Healing in Colonial India, (New York: Routledge), pp. 213-228

${ }^{46}$ See for instance, James Secord (2006), 'Scrapbook Science: Composite Carictures in Late Georgian England', in A. Shteir and B. Lightman (eds), Figuring It Out: Science, Gender, and Visual Culture, (Hanover, New Hampshire: Dartmouth College Press), pp. 164-191

${ }^{47}$ Mott Greene (2007), 'Writing Scientific biography', Journal of the History of Biology, 40,4, pp. 727-728 . Also see, Mary Terrall (2006), 'Biography as a Cultural History of Science', Isis, 97,2, pp. 306-313

${ }^{48}$ Richard Yeo and Michael Shortland (ed) (1996), Telling Lives in Science: Essays in Scientific Biography, (Cambridge: Cambridge University Press). 
the eighteenth century German founder of the doctrine, to careers of who were highlighted as 'extraordinarily successful and efficient' medics, to lives of medical entrepreneurs (mostly also physicians) invested in the production of homoeopathic drugs, print and knowledge. Biographies narrating individual lives varied in size from slender, cheap, vernacular pamphlets or monographs of few anna (one-sixteenth of a rupee) to heavier, more expensive English tomes. In addition, lives of practitioners were published serially in foremost English language journals published, edited and printed by the leading Calcutta-based homoeopathic family-firms. Some of these were the Indian Homoeopathic Review (published by the Majumdar's Pharmacy), Homoeopathic Herald and Homoeopathy Chikitsha (published by M.Bhattacharya and Company), Hahnemann and The Hahnemannian Gleanings (published by Hahnemann Publishing Company) and most importantly the Calcutta Journal of Medicine edited and published by Mahendralal Sircar and his son Amritalal Sircar uninterruptedly from1867 to at least 1913. In its heydays under Mahendralal, limited copies were sent for sale in London. ${ }^{49}$ Indeed, while most journals boasted of a readership beyond the urban centres into the mofussils, few others recurrently highlighted in their editorials of their 'numerous subscribers- clients and readers, within and outside India... ${ }^{50}$ Admittedly, fund shortages and problems of arrears in running the journals too were occasionally reported. ${ }^{51}$

Yet, these hardly exhausted the formats through which lives of Bengali homoeopaths were addressed to the readers. True to the current characterisation of biography as a 'hybrid, unstable genre with many forms ${ }^{, 52}$, life stories of physicians appeared in myriad formats and on remarkably different pretexts. Prefaces, forewords and even dedication pages of books on homoeopathic therapeutics, articles and published lectures in journals, advertisements, journal editorials, obituaries, poems, published conference papers read out to international homoeopathic congresses regularly served as platforms for narrating either fragmented or comprehensive lives of various 'key figures instrumental in the spread of homoeopathy in Bengal'. This article draws upon around sixty-four such biographies, the bulk of them appearing as stand-alone books or serialised biographies in journals.

Indeed, spanning the last quarter of nineteenth and the first half of the twentieth century, there seems to have flourished around homoeopathy, what in other contexts have come to be described variously as a 'biography industry' ${ }^{53}$ or a 'biographical mania. ${ }^{54}$ These characterisations referring primarily to the demand, production, reading of such biographies, as also the agency and interest of the biographers can be usefully invoked to understand the nature of the homoeopathic biographic productions in Bengal. An enduring interest in these lives can be assessed from the many biographic works undertaken as also by the myriad remarks, queries, and letters in response, sent to the editors following the publication of these lives. Such readership was often not restricted to the particular journal where the biography was originally published. Rivalry between journals was often exposed in context of the information conveyed in the life stories. An editorial of the journal Hahnemann, for example, engaged in a protracted polemic with a rival journal Homoeopathic Samachar, over the details of Rajendralal Datta's life, which they had published a few months back. ${ }^{55}$ The

\footnotetext{
${ }^{49}$ Arun Kumar Biswas (ed.) (2000), Gleanings of the Past and the Science Movement: In the Diaries of Drs. Mahendralal and Amritalal Sircar, (Kolkata: Asiatic Society), p.16

50 'Editorial', Indian Homoeopathic Review, 15, 1, January 1906, pp. 1

${ }^{51}$ See for instance, Arun Kumar Biswas (ed.), Gleanings of the Past, p. 16

52 Julie Codell (2003), The Victorian Artist: Artists' Lifewriting in Britain c. 1870-1910, (Cambridge:

Cambridge University Press), p. 2

${ }^{53}$ Allen Hibbard (2006), 'Biographer and Subject: A Tale of Two Narratives', South Central Review, 23, 3, p.31

${ }^{54}$ Julie Codell (2000), 'Constructing the Victorian Artist: National Identity, the Political Economy of Art and Biographical Mania in the Periodical Press', Victorian Periodicals Review, 33,3, pp. 283-316

55 'Editorial: Daktar Rajendralal Dutta Sambandhe Homoeopathic Samachar er Uktir Uttor' ('Reply to the Remark on Dr. Rajendralal Dutta by Homoeopathic Samachar'), Hahnemann, 22, 3, 1939, pp. 181-183.
} 
narrators too seemed to be aware of the extensive demand and wide ranging circulation of their work. Writing in 1909, a biographer of Mahendralal Sircar expressed his conviction regarding the sale of his book, 'As many educated Indians like Homoeopathy now-a-days, there is every likelihood of my book being sent to or purchased by them in most educated households... ${ }^{56}$ Such confidence was reaffirmed by the proliferation of many published biographies into multiple editions. The preface to the fourth edition of Mahesh Chandra Bhattacharya's life, published by his own family firm, pompously noted that the account was inspired by wide ranging interest in the life among a Bengali reading public. ${ }^{57}$

Inevitably, this plethora of biographies focussed not only on communicating the events in the lives of the personalities, but more significantly on what those lives meant. The life stories seemed to perform as cheaper, popular and more accessible extension to the proclaimed scientific literature. Written in lucid prose for a mass audience, they complemented the more explicitly medical treatise in establishing homoeopathy's genealogy as well as its fundamental principles in the way artists' biographies have been shown to operate as complementary texts to actual museum visits and obtuse art criticisms in Britain. ${ }^{58}$ In their meticulous recounting of the founding moment of homoeopathy, the German physician Hahnemann's discovery of the so-called 'law of similars' 59 , the many lives of Bengali homoeopaths emphasised at once the uniqueness, antiquity and by extension, the superiority of the doctrine. A typical biography of Hahnemann titled Homoeopathy Abishkorta Samuel Hahnemann er Jiboni (Biography of Samuel Hahnemann, the Discoverer of Homoeopathy) written in 1881, for instance, devoted the initial chapters discussing the discovery that enunciated the homoeopathic theories of healing around the 'law of similars', along with Hahnemann's notion of bodily vital force and its derangements as the cause of disease as also the homoeopathic rationale for minute doses for drugs. ${ }^{60}$ Simultaneously trying to persuade the audience of the antiquity as well as the novelty of homoeopathic principles as compared with doctrines such as ayurveda, texts like Susrut o Hahnemann (Life of Susruta and Hahnemann) published in 1906 asserted that although the possibility of cure by similars was included in ayurveda and other ancient texts, it was not elaborated in a 'systematic and disciplined manner' before Hahnemann. ${ }^{61}$ It argued that the greatness of Hahnemann lay in developing a nascent principle inherent in ayurveda into a coherent body of knowledge. ${ }^{62}$ Together, these life stories seemed to proffer themselves as a contextual literature to understand the central homoeopathic text the Organon, much as religious biographies were often conceived as preparatory texts for their relevant scriptures. ${ }^{63}$

Apart from the canonicity, claims of homoeopathic superiority hinged crucially on the evocative depiction of distinct typology for the physicians' characters. The texts were careful in highlighting the deep moral integrity of their personality, their righteous commitment

\footnotetext{
56 Sarat Chandra Ghose (1909), Life of Dr. Mahendralal Sircar, (Calcutta: Oriental Publishing Home), first edition, p. 55.

57 Mahesh Chandra Bhattacharya (1957), 'Preface', Atmakatha (My Life), Calcutta: Economic Press, Fourth Edition, page number not cited. Likewise, the monograph Life of Dr. Mahendralal Sircar first published in 1909 was republished in 1935 by Hahnemann Publishing Company on grounds of 'increasing popular demand'.

${ }^{58}$ Julie Codell, The Victorian Artist, pp. 6-7

59 The Latin phrase 'similia similibus curatur', meaning 'like cures like', popularly referred to as the 'law of similars', was widely written about as the core principle of homoeopathy as enunciated by Hahnemann.

${ }^{60}$ Mahendranath Ray (1881), Homoeopathy Abishkorta Samuel Hahnemann er Jiboni (Biography of Samuel Hahnemann, the discoverer of Homoeopathy) (Taligunj: Kasi Kharda Press), pp. 3-17

${ }^{61}$ Surendra Mohan Ghosh (1906), Susrut o Hyaniman (Susrut and Hahnemann), (Calcutta: Bengal Medical

Library), pp. 2, 6-11

${ }^{62}$ Ibid, p. 63

${ }^{63}$ See Wianad Callewaert and Rupert Snell (ed.) (1994), According to Tradition, : Hagiographical writing in India, (Harrasowitz Verlag Wiesbaden), pp. 12-13
} 
towards curing social ills. Beyond the mere materiality of drugs, homoeopathy was portrayed as a biomoral regimen of disciplining lives. The practice of homeopathy was projected to ensure the cultivation of an ethical holistic vision of being. Acquisition and dispensation of wealth remained the two fundamental tropes around which narration of the lives were organised. At one level, homoeopathy's superiority and efficacy was emphasised through careful depiction of its growing popularity across Indian society. Rajendralal Datta's biography described how 'a crowd of eager patients assembled in his house every morning with the punctuality that marks the rising of the sun in the east and as cure followed cure, the crowds grew'. ${ }^{64}$ The fact of being summoned by eminent, even princely clients was meticulously recorded as an obvious marker of the doctrine's efficacy. Hence, while the life history of D.N.Ray noted the names of Dadabhai Naoraji, the founder of the Indian National Congress and Byaramjee Malabari, the famous Parsi reformer and editor of the newspaper Spectator among his patients, ${ }^{65}$ other biographies narrated the reputation of these physicians among the princely states of India such as the Nawab of Bhopal. ${ }^{66}$ Apart from the native elites, the names of Englishmen who regularly consulted Bengali homoeopaths featured in these narratives. Rajendralal Datta's life recorded Lord Ripon, Sir Henry Cotton, Sir Peacock, Sir Risley, Sir Harrison, Sir Lambert, Mr Robert Night (editor of the newspaper Statesman), Father Lafont, as among his habitual patients. ${ }^{67}$ In a related vein, wealth acquired by the physicians was upheld as a palpable measure of both their own repute and homoeopathy's worth. Wealth was often assessed in terms of the property they managed to acquire and the fortunes one left behind. ${ }^{68}$ The life stories were dotted with minutiae of the palatial residences the protagonists had built. ${ }^{69}$

Yet significantly, along with the discussions on acquisition, there was a veritable valorisation of the ability to give up the acquired wealth. Narrations of these lives delineated an ethic around codes of dispensation of wealth that was integrally related with notions of 'seba' or 'service', 'kalyan' or 'wellbeing' and 'tyag' or 'sacrifice'. ${ }^{70}$ We will have occasion to discuss the (often explicit) Hindu nationalist undertone of these tropes in the third section of this paper. For now, it is important to note that 'Seba' or service to the poor and the distressed was considered the most ethical means of dispensing wealth. Homoeopathy was upheld as a powerful ideology that empowered its protagonists to achieve that desired end as a range of biographies detailed their commitments towards 'distributing medicines and food free of cost amongst the sick poor and to minister to their comforts in every imaginable

${ }^{64}$ S.C. Ghose, 'Homoeopathy and Its First Missionary in India', pp. 451.

65 D.N. Ray (1929), Daktar D.N. Ray er Atmakatha (Autobiography of Dr D.N.Ray), Publisher not cited, 1929, pp. 273

${ }^{66}$ Sarat Chandra Ghosh (1939), 'Dr.L.Salzer M.D', Hahnemann, 22, 6, pp. 326-7.

${ }^{67}$ Saratchandra Ghosh (1939), 'Bharatbarshe Homoeopathy Chikitshar Sorbo pratham

Pathopradarshak o Pracharak Dr. Rajendralal Datta' ('The Pioneer Physician and Perpetrator of Homoeopathy in India'), Hahnemann, 22, 1, pp. 19.

${ }^{68}$ Biographies and autobiographies of most physicians including Batakrishna Pal, Pratap Chandra Majumdar, Lokenath Maitra, D. N. Ray etc have elaborate details of their property acquired through homoeopathic enterprise. For instance, see, Jitendranath Majumdar (1940), 'Dr. Pratap Chandra Majumdar M.D', Hahnemann, 23, 8, pp. 452-453.

${ }^{69}$ For instance see Sarat Chandra Ghosh (1940), 'Dr. Brajendranath Bandopadhyay M.D', ,Hahnemann, 23, 3, p. 133. Also see, Gopal Chandra Mukhopadhyay (1919), Sadhu Batakrishna Pal (Batakrishna Pal, the Great) , Vol II, (Calcutta: Batakrishna Pal), pp. 168169

70 See for instance, Rashbehari Mukhopadhyay (1921), 'Shworgiyo Raysaheb Dinabandhu Mukhopadhyay er Jiboni’ (Life of Late Honourable Rashbehari Mukhopadhyay), Hahnemann, 4,8, p. 293 
way. ${ }^{71}$ Lives of Mahendralal Sircar, Mahesh Chandra Bhattacharya, Brajendranath Bandopadhyay, Akshay Kumar Dutta and Batakrishna Pal recounted innumerable instances of their selfless help and empathy towards the poor in the form of free treatment and free distribution of drugs. ${ }^{72}$ At the death of Akshay Kumar Dutta, destitutes were recorded to have lamented that "the rich people of the country have many renowned doctors to look after them. But he was like a parent to the poor and the hapless, who had no one else to turn to'. ${ }^{73}$ Mahesh Chandra's role in reducing the price of homoeopathic drugs in his Economic Pharmacy was narrated as an exemplary instance of his service to the people. ${ }^{74}$ The biographies claimed such services to have a bearing on the welfare of the nation as a whole. ${ }^{75}$

Related to the discourse of 'service' around homoeopathy, was the emphasis on charity. Charity or 'Daan' was glorified as the noblest way of utilizing the wealth acquired through homoeopathic practice. Whether devoting a whole chapter titled 'Daan Brata' (Codes of Charity) in Batakrishna Pal's biography or discussing Mahesh Chandra as author of texts as 'Daanbidhi', most homoeopathic biographies upheld their protagonists as those engaged in acts of (often anonymous ) charity for the selfless good of society. Discussions on ethical utilisation of wealth further encompassed extraordinarily simple everyday lifestyle of the protagonists involving diet, clothing and other quotidian habits. Of Mahendralal Sircar's personal lifestyle it was carefully noted that the physician 'always wore Taltollah slippers; whether visiting patients or attending public meetings. The Calcutta public does not remember having seen him in boots or shoes... He more resembled an old poor Brahmin in these respects than a successful medical practitioner of the town. ${ }^{, 76}$ Likewise, Batakrishna Pal's biography recorded that even with spectacular changes in fortune, his appearance remained unaltered over the years. ${ }^{77}$ The biographer mentioned having seen him in the same simple attire for over fifty years. Men such as Mahesh Bhattacharya categorically condemned extravagance of any kind as sin, especially in a poor, subjugated economy as India. ${ }^{78} \mathrm{He}$ held that the cunning colonial powers dominated other nations by luring them into a luxurious lifestyle that played havoc with the prevalent social norms.

The agency of biographies in shaping cultural memory has been acknowledged in recent works. ${ }^{79}$ The recurrent typologies deployed in the narration of homoeopathic lives equated the moral propensities of physicians with the inherent value of their doctrine. Virtues of the individual lives were perceived to be inseparably linked with the craft they practiced. The

\footnotetext{
${ }^{71}$ S.C.Ghose (September 1932), 'Homoeopathy and Its First Missionary in India', The Hahnemannian Gleanings, 3, 8, pp. 338-339.

${ }^{72}$ For instance see Rashbehari Mukhopadhyay (1921), 'Shworgiyo Raysaheb Dinabandhu Mukhopadhyay er Jiboni'(Life of Late Honourable Rashbehari Mukhopadhyay), Hahnemann, 4, 7, p. 147.

${ }^{73}$ Sarat Chandra Ghosh (1940), 'Dr. Akshay Kumar Datta L.M.S', Hahnemann, 23, 4, p. 199

${ }^{74}$ Srish Chandra Talapatra (1946), Maheshchandra Charitkatha (Life of Mahesh Chandra), (Calcutta: Economic Press), pp. 31-32

75 Ibid, Also see, Rashbehari Mukhopadhyay, 'Shworgiyo Raysaheb Dinabandhu Mukhopadhyay er Jiboni' (Life of Late Honourable Dinabandhu Mukhopadhyay), p. 147.

76 Shivnath Shastri (1918, Reprint Dey's 2003), 'Men I Have Seen', Atmacharit (My Life), (Calcutta: Prabasi

Karjalay), pp. 503-504

${ }^{77}$ Gopal Chandra Mukhopadhyay, Sadhu Batakrishna Pal (Batakrishna Pal, the Great), Vol II, pp. 205-207

${ }^{78}$ Srish Chandra Talapatra, Mahesh Chandra Charitkatha, pp. 77-78

${ }^{79}$ Richard Holmes (2002),' A proper Study?' in William St Claire (ed) Mapping Lives: The Uses of Biography, Oxford University Press, $p .12$
} 
underlying assumption animating the narration of these lives was to sensitise the readers towards an ethically committed personalised care regime promised exclusively by a heterodoxy like homoeopathy, distinct from the strictly institutional, depersonalised structures of state medicine. Underlining the impact of these individual lives on larger society, the biographies construed the image of a knowledgeable, compassionate, hardworking, selfless, austere physician as the ideal type for an emerging nation.

\section{Biography, History and a Familiar Science}

Such remarkably expedient representation of homoeopathy through practitioners' life stories, I argue, was often facilitated by the practitioners' considerable agency in the biographic market. In her insightful work on artists' biographies in nineteenth century Britain, Julie Codell demonstrate that through the nineteenth century, Victorian artists increasingly 'came to control their public image....became their own agents for the circulation and reproduction of their identities as well as of their works.' ${ }^{80}$ She elaborates on the intimate friendships with the critics, journalists and art dealers through whom artists indirectly ended up shaping their public image. Relations of 'intimacy' and 'familiarity' were, in fact, crucial determinants in shaping homoeopathy through life writings. Indeed, as we noted in the introduction, at the heart of the homoeopathic discourse in colonial public culture was a range of intergenerational family-firms. Late nineteenth century Bengal saw the advent of a number of business concerns that began investing in the production of homoeopathic drugs, print and knowledge over generations. Situated at 12, Lalbazar Street and owned by Rajendralal Datta (1818-1889) and later his nephew Ramesh Chandra Datta, Berigny and Company's Calcutta Homoeopathic Pharmacy was supposedly 'the first and the oldest' homoeopathic pharmacy. Besides Berigny and Company, Majumdar's Pharmacy run by physician Pratap Chandra Majumdar along with son Jitendranath Majumdar, the establishment of the Sircars headed by the famous physician Mahendralal Sircar and his son Amritalal Sircar, M. Bhattacharya and Company headed by Mahesh Chandra Bhattacharya and sons, B.K.Pal and Company owned by Batakrishna Pal and his sons as also Prafulla Chandra Bhar and sons, owning the Hahnemann Publishing Company were some of the most prominent business concerns dealing in homeopathic publications and pharmacies. Asserting their familial, intergenerational presence in the field of homoeopathy, the protagonists of these business concerns self-consciously upheld a distinct form of enterprise delineated as 'family business' ${ }^{81}$

The biography industry around homoeopathy was fundamentally held together by these commercial firms as they assumed multiple overlapping roles in relation to the printed lives. The entrepreneur-physicians and their firms were primarily the patrons and publishers, but also frequently the authors and almost invariably the subjects of the life stories. Apart from explicit blood relations, the biographies repeatedly also highlighted near-familial relationships of friendship, alliance and intimacy between protagonists and eminent physicians related to these firms. Exceptional professional camaraderie between the entrepreneur-physicians was projected as a hallmark of the family-firm based homoeopathic commerce, as the mouthpiece journals recurrently emphasised that 'harmony should be the basic principle upon which true friendship and good business can last and flourish.

\footnotetext{
${ }^{80}$ Julie Codell, The Victorian Artist, pp. 8-9

${ }^{81}$ For a more detailed discussion on the homoeopathic practice of family business through intergenerational family firms, see Shinjini Das, Homoeopathic Families, Hindu Nation and the Legislating State: Making of a Vernacular Science, Bengal 1866-1941, Unpublished PhD dissertation, University College London, 2012, pp. 37-80.
} 
Selfishness, greed, enmity, rivalry and mutual vilification do away with and undo that which it took years to build up... ${ }^{82}$ Further, the biographies narrated cordial interpersonal relations also in reference to an informal network of pedagogy and pupillage shared between the foremost entrepreneur-physicians, their descendants, students and associates. An illustrative example is the relation between Rajendralal Dutta and Mahendralal Sircar. All printed lives of both physicians dramatically highlighted the way Rajendralal inducted Mahendralal to the principles of homoeopathy, inspiring him to 'convert' from orthodox state medicine learnt at the Calcutta Medical College to homoeopathy, and that Mahendralal remained eternally grateful to the former, acknowledging him as his mentor. ${ }^{83}$ Rajendralal's life story quoted at length Mahendralal's emotional outpourings following the former's death,

...he used to call me his 'father and son', and subscribe himself in all the letters he wrote to me as 'your son and father'. The love that he bore me was not a whit less than that of a father to his son. His faith in me as you know was unbounded. His reverence for me was that of a son. Could I be undutiful to such a man? My personal loss in his death is more than that of any other man. ${ }^{84}$

As fathers and sons, uncles and nephews, teachers and students, mentors and disciples often ended up sharing relations in print as authors, publishers and subjects of homoeopathic biographies, it is important to situate the homoeopathic life writings within these complex processes of their publications. More striking than the rhetoric and reality of 'family', perhaps, is the fact that such relationships of intimacy were highlighted variously and recurrently in print. The meticulous and persistent proclamations of familial, affective relationships between those propagating homoeopathy had the effect of construing homoeopathy as an overwhelmingly family-oriented science. Not only was it meant for the consumption of colonial domesticities, homoeopathy was projected as a science that was even produced within the realm of colonial family. In that, its history resonates with those of other unorthodox practices like ayurveda and unani, whose linkages with traditional intergenerational practicing families has been fleetingly hinted in the historiography. ${ }^{85}$ Further, these narrative approaches publicised Bengali homoeopathy as an emotive, informal, personalised and familial domain of a range of men committed to a shared mission of popularising an unorthodox, European science for national good. Homoeopathy was espoused as the moral tool in the hands of a group of intimate men committed to improve the medical landscape of Bengal.

Such tropes of an informal, familiar, intimate network had serious ramifications for the proclaimed purpose of the biographies. Beyond the immediate narrow agenda of chronicling individual lives, the Bengali biographies, almost always, shared wider convictions of a more lofty purpose for narrating individual lives. The authors frequently paused to reflect on the importance of biography as an academic genre and included their thoughts on the very act of writing and recording the lives they did. They referred to an entrenched Victorian culture of

\footnotetext{
82 'Editorial: New Year's Retrospection and Introspection', The Hahnemannian Gleanings, 4, 1, February 1933, pp. 10-11.

${ }^{83}$ For instance see, Sarat Chandra Ghosh (1939), 'Bharatbarshe Homoeopathic Chikitshar

Sorboprothom Pothoprodorshok o Pracharak Dr. Rajendralal Dutta' (The Pioneer Perpetrator of Homoeopathic Treatment in India Dr Rajendralal Dutta), Hahnemann, 22, 1, pp. 14-16.

${ }^{84}$ Sarat Chandra Ghose, 'Homoeopathy and its First Missionary in India', pp. 449- 450.

${ }^{85}$ For a discussion of the Muslim elite families like the Azizi family in the modernisation of traditional Unani see Seema Alavi (2008), Islam and Healing: Loss and Recovery of an Indo-Muslim Healing Tradition 16001900, (Basingstoke: Palgrave Macmillan), pp. 14-16. For similar powerful presence of 'hereditary' practicing families like that of Bhai Mohan Singh Vaid or Hakim Ajmal Khan and their ties with commercial print and phamaceuticals see Kavita Sivaramakrishnan (2005), Old Potions, New Bottles: Recasting Indigenous Medicine in Colonial Punjab (1950-1945), (Hyderabad: Orient Longman), pp.106-108
} 
writing and memorialising lives of eminent personalities. By contrast, it was regretted that the Indians compared dismally in celebrating and recording prominent lives for posterity. Referring to Rajendralal Dutta's entrepreneurial skills one biography lamented, '... had he been born among more appreciative people, they would certainly have recognised in him the stuff of which the Howards and the Hampdens are made... ${ }^{\text {, }}$

The authors contended biographies as a significant means of recording the past. Indeed, through biographies, most authors claimed to have been engaged in the writing of history. While the relationship between biography and history has been a matter of much unresolved concern with historians of our times, somewhat unusually for late nineteenthearly twentieth century writers, many biographies defined their proclaimed function as the chronicling of the history of their time. They emphasised an integral relation between individual lives and the history of the times they lived in. It was argued that the "personal element plays so important a part in the history of every moment that no one can afford to ignore it or to treat it with indifference. ${ }^{, 87}$ To them, narrating a life dedicated to the cause of homoeopathy was the most effective way of recounting and recording homoeopathy's history. A monograph on the life of Mahendralal Sircar, for instance, declared at the onset,

The life of Dr. Sircar was connected in such imperishable links with the history of Homoeopathy in India that any attempt to write a biography of this great man necessitates a fair exposition of the Rise and Development of Homoeopathy in India and any biography bereft of it will not be found to be interesting and withal it will prove the incompleteness of the book. ${ }^{88}$

Hence, narrating histories of homoeopathy and writing biographies of significant physicians were considered analogous and equivalent processes. A number of journals like The Hahnemannian Gleanings launched serial publication of biographic sketches of important personalities to give its readers 'a taste of the history of homoeopathy in India' ${ }^{89}$

It is noteworthy that the late nineteenth- early twentieth century biographer-physicians felt compelled to speak in the language of 'history'. The historiography tracing the emergence of a nationalist consciousness has elaborated on the crucial importance attached to the writing of pasts of the nation. ${ }^{90}$ They have shown how such writings in Bengal since the mid nineteenth century were increasingly imbued with post enlightenment thinking that regarded the western rationalist- positivist notion of 'History' as the most desirable mode of knowing the past of a people. ${ }^{91}$ The deep intertwine between the struggle for a national identity and the writing of history resulted in a proliferating culture of public engagement with history in late nineteenth-century

\footnotetext{
${ }^{86}$ S.C.Ghose (September 1932), 'Homoeopathy and Its First Missionary in India', The Hahnemannian Gleanings, 3,8, p. 339.

87 S.C.Ghose (August 1932), 'Homoeopathy and Its First Missionary in India', The Hahnemannian Gleanings, 3,7, p. 294.

${ }^{88}$ Sarat Chandra Ghose (1935), Life of Dr. Mahendralal Sircar, Second Edition, (Calcutta: Hahnemann Publishing Company), p. 27

89 'Editorial Notes and News: Reminiscences of Old Torch-bearers of Homoeopathy in India', The Hahnemannian Gleanings, 9, June 1939, pp. 266-67.

${ }^{90}$ Partha Chatterjee (1993), Nation and Its Pasts, The Nation and Its Fragments: Colonial and Postcolonial Histories, (New Jersey: Princeton University Press), pp. 88-94. Also see Daud Ali (ed.) (2002), Invoking the Past: The Uses of History in South Asia, (Delhi: Oxford University Press)

${ }^{91}$ Partha Chatterjee, Nation and Its Fragments, , pp.88-92
} 
Bengal. ${ }^{92}$ The compulsion of the Bengali physicians to identify their biographic endeavours as history can be mapped within this early-twentieth-century proclivity towards what has been described as an "enormous public enthusiasm for history."93 In their eagerness to write histories through biography, the authors were often drawn into the early-twentieth-century concerns over the writing of credible histories. Indeed, what constituted history was a contentious topic in late colonial India. Works of Dipesh Chakrabarty show the growing ascendancy of the notion of professional, 'scientific' history in India since the late nineteenth century, informed by an entrenched faith in the Rankean rationalist-positivist understanding of objective, unbiased historical truth. ${ }^{94}$ However, others have attempted to unravel the limits to such notions of 'scientific' history among parts of Indian intelligentsia. ${ }^{95}$ In her analysis of the early-twentiethcentury controversies surrounding the status of Kulagranthas (a specific kind of genealogical literature), Kumkum Chatterjee, for instance, shows the persistence of parallel notions of history among various sections of Bengali society, which she designated as popular/romantic history that valued emotion, memory, community etc over any idealised notion of objectivity or rationality promoted by scientific history. ${ }^{96}$ Operating within this intellectual milieu, the physician-biographers too, I argue, came to represent another faction of the Bengali intelligentsia that registered their differences with the plausibility of the mandate of scientific history. From a pragmatic standpoint, they ended up critiquing the notion of 'objectivity' and privileged the virtue of 'familiarity' and 'intimacy' as more fundamental in writing biographies. Biographies as a genre, these authors argued, thrived essentially on the intimate, familial, private and informal sources of information.

Drawing upon and engaging with contemporary notions of 'objectivity' and 'rationality', these texts, nonetheless, hinted at their limits when it came to writing credible biographies. Thus, at one level, in a published lecture on Hahnemann's birth anniversary in 1887, Mahendralal Sircar alerted his readers about the importance of writing objective, critical biographies that did not degenerate into hero worship of its subjects. ${ }^{97}$ Mahendralal warned that such exercises made 'men and events acquire a magnitude and an importance which they do not intrinsically possess. ${ }^{98}$ Before narrating a biography of Hahnemann himself, he reflected upon the importance of a critical biography to 'judge of him as a man, and of his place in the history of science and

\footnotetext{
92 Partha Chatterjee, The Nation and Its Fragments, pp. 109-115.

${ }^{93}$ Dipesh Chakrabarty (2008), 'Public life of history: An Argument Out of India', Public Culture, 20, 1, p. 145 Also see Kumkum Chatterjee (2005), 'The King of Controversy: History and Nation Making in late Colonial

India', American Historical Review, 110, 5, pp.1454-1455

${ }^{94}$ Dipesh Chakrabarty, 'Public life of history', pp. 145-146 and Dipesh Chakrabarty (June 2009), 'Bourgeois categories made Global: Utopian and Actual Lives of Historical Documents in India', Economic and Political Weekly, 44, 25, p. 68. Also see Dipesh Chakrabarty (2011), 'The Birth of Academic Historical Writing in India', in Stuart Macintyre et al (eds.) The Oxford History of Historical Writing, Vol 4: 1800-1945, (Oxford: Oxford University Press), pp.528-529

${ }^{95}$ See Partha Chatterjee and Raziuddin Aquil (ed.) (2008), History in the Vernacular, (Delhi: Permanent Black), pp. $1-22$

${ }_{96}^{96}$ See Kumkum Chatterjee, 'The King of Controversy', pp. 1464-1475

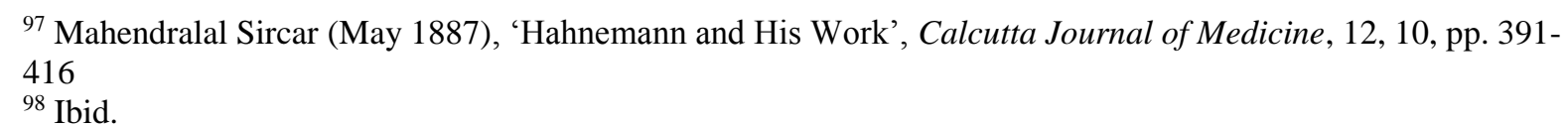


medicine. ${ }^{99}$ Such analytic distance was often measured in terms of temporality. Thus, in his introduction to the Life of Dr. Mahendralal Sircar, the author gave vent to his anxiety relating to the timing of the act of his writing. He was aware that,

He [Mahendralal] lived so long and lived so manfully and nobly and was so warmly cherished in the affection of numerous readers that it still seems too soon to venture on a critical estimate of his labours and works in the world. ${ }^{100}$

Yet, the authors were equally concerned with the other crucial requirement of scientific history, viz, collection of verifiable facts. To them, access to reliable sources and information was far more fundamental in the writing of biographies. They pointed out that accessing sources and verifiable facts were necessarily related to the familiarity and intimacy one shared with one's biographic subject. They unequivocally confessed that the virtues of 'intimacy', 'affective attachment' and 'familiarity' with sources had been, for them, fundamental in writing biographies. Accordingly, the biographies routinely highlighted the closeness and intimacy between its authors and subjects.

Indeed, the reliability and verifiability of the information they furnished in their texts was shown to be inherently predicated on such intimacies. The truth claim of biographies was shown to rest on the perceived intimacies between the author and the subject. Most biographies included the identity of the biographers in the form of acquaintances ranging from sons, brother-in-laws, sons-in-laws, to close family friends or professional associates. While the biographer of Mahesh Bhattacharya informed the readers of his fifty years of association with the family in the very first page of his book, biographer Jitendranath Majumdar made no efforts to conceal his deepest reverence for his father physician Pratap Majumdar. ${ }^{101}$ The personal affective elements were played up to an extent that the biographer of Batakrishna Pal, his friend and fellow homoeopath, expressed his deep sense of loss and helplessness at Batakrishna's death. ${ }^{102}$ In instances where familial and other intimate friendships were not asserted, a sense of an exceptional professional camaraderie exuded out of the texts. Sarat Chandra Ghosh, himself a homoeopathic practitioner, editor of the widely circulating The Hahnemannian Gleanings and author of many serialised biographies in journals, expressed his excellent relationship with all his subjects. He quoted personal conversations and letters, described private meetings and the like in his biographies. His biography of Mahedralal Sircar in the journal Hahnemann, for instance, had an entire section elaborating the 'extremely amicable relation' between them. ${ }^{103} \mathrm{Such}$ shared closeness with the subject rendered his portrayal of Mahendralal's life as 'most reliable' as compared to other biographies of the physician. ${ }^{104}$ At the same time, the biographer of Mahesh Bhattacharya revealed his anxiety in being too intimate "with not

\footnotetext{
99 Ibid.

${ }^{100}$ S.C. Ghose, Preface, Life of Dr. Mahendralal Sircar, First Edition, p. i.

${ }^{101}$ Srish Chandra Talapatra, Maheshchandra Charitkatha (Life of Maheshchandra), p. 3. Also see J.N.Majumdar (1940), 'Dr. Pratap Chandra Majumdar MD', Hahnemann, 23, 5, pp. 261-267

102 Gopal Chandra Mukhopadhyay (1919), Sadhu Batakrishna Pal (Batakrishna Pal, the Great), Vol II, (Calcutta: Batakrishna Pal), pp. 191, 292

${ }^{103}$ Saratchandra Ghosh (1939), 'Daktar Mahendralal Sircar er Jibon-katha' ('Life of Dr. Mahendralal Sircar'), Hahnemann, 22, 3, pp. 137-141.

104 Saratchandra Ghosh (1939), 'Daktar Mahendralal Sircar er Jibon-katha' ('Life of Dr. Mahendralal Sircar'), Hahnemann, 22, 2, pp. 67-71
} 
only Bhattacharya, but his entire family. ${ }^{, 105}$ In a self-critical mode, he elaborated on the possible hindrances to objective analysis that such long-term familiarity engendered. ${ }^{106}$

Hence, while establishing the relation between biography and history, the physicianbiographers unravelled a methodological dilemma between cultivating historical objectivity and procurement of sources. Biography was projected as a kind of history that essentially privileged the virtues of 'intimacy' over any idealised notions of objectivity. In their pragmatic rejection of objectivity, the homoeopathic biographies constituted an important counterpoint to the emerging academic project of writing 'scientific' history. Their quandary between objectivity and intimacy, hinted towards the larger issues of politics of archiving and the problem of sourcing related to the craft of writing history. In his recent work Dipesh Chakrabarty unravels the problematic nature of public archives in early twentieth century India in showing how 'facts' or 'sources' were often caught up within various kinds of 'privileged communities.' 107 Access to such networks or communities was often determined through private relations of friendship and enmity. With specific examples from Bengal and Maharashtra, he demonstrates how the process of accessing 'original' historical sources for public consumption was often fraught with hidden stories of enmity, rivalry, friendship, inheritance and alliance. ${ }^{108}$

More general scholarship on knowledge formation in the nineteenth century too show the centrality of networks of friendship, alliance and intimacy as crucial, latent determinants of knowledge and history. ${ }^{109}$ The processes of consolidation of homoeopathy through public assertions of intimacy contributes to this scholarship. Further, in privileging 'intimacy' and 'familiarity' over objectivity, the homoeopaths, as practitioners of a family-oriented, informal, intimate science, avowed a special status for themselves, as indeed other sectarian groups caught up in family, caste, kinship or sacred networks, as producers of authoritative biographies.

\section{Writing Lives, Translating Science}

Between construing homoeopathy as a family-oriented intimate science and an ethically charged moral regimen of living, the biographies considerably translated the image of homoeopathy from an essentially rational, western scientific doctrine. The life stories, in fact, simultaneously celebrated homoeopathy as a western marvel as well as a faith based Indian spiritual practice, embedded in indigenous tradition. Poised within such contrarian framework, the texts carved out a liminal status for both homoeopathy and its eighteenth century German pioneer Hahnemann as radically western yet deeply chiming with Hindu spiritual values.

Circulation and localisation of science in the imperial world has emerged as a significant strand in understanding the genealogy of modern science and medicine. There is a rising interest in analysing the linguistic and sociocultural strategies by which doctrines, concepts, terms and even theoretical constructs are made legible across cultural borders and rendered stable over time. Referring to the process as one of 'translation' and

\footnotetext{
${ }^{105}$ Srish Chandra Talapatra, Maheshchandra Charitkatha, pp. 3-4.

106 Ibid.

${ }^{107}$ Dipesh Chakrabarty, 'Bourgeois categories made Global', pp. 67-68

${ }^{108}$ Ibid, pp. 71-74

109 William Lubenow (2005), ' Intimacy, Imagination, and the Inner Dialectics of Knowledge Communities: The Synthetic Society, 1896-1908' in Martin Daunton, (ed.), The Organisation of Knowledge in Victorian Britain, (Oxford: Oxford University Press), pp. 357-370
} 
realignment of power rather than imposition, Gyan Prakash was one of the earlier South Asianists to foreground how scientific ideas across cultures effected 'inappropriate transformations', and displacements in meanings. ${ }^{110}$ More recent works have dwelt upon the processes through which colonial science became a mode of 'enchantment' of Indian modernity. ${ }^{111}$ There is an increasing emphasis now to explore specifically the local embeddednes of such knowledge production as also to study the particular impact of such translations on the languages concerned. ${ }^{112}$

While drawing upon and speaking to these works, the case of homoeopathy's circulation in Bengal underlines the centrality of local factors and interest groups as well as the contingencies of the vernacular print market in rendering homoeopathy national. It illustrates that the displacements in meaning associated with 'translation' could also occasionally be deliberate, premeditated and self-conscious. The journals that published many of the biographies also carried articles discussing the translatability of science across contexts. ${ }^{113}$ Literal assimilation was dismissed as inadequate if it did not take into account the specific context of Bengal; its physical and emotional landscape, as also its national context. The authors repeatedly and purposefully pointed out that although 'homoeopathic science is their science, to be able to use it in India, we need to adapt it to our situation and make it our own'. ${ }^{114}$ It was held that while translating western doctrines it was not advisable to follow their contents unconditionally and completely. ${ }^{115}$ Along with differences in physical conditions including climate, food habit, dressing patterns and the like, the authors especially emphasised the cultural divergences between India and the west. ${ }^{116}$ Along with such self -conscious processes of assimilation, the adoption of a Hinduised vocabulary reinforces stereotypes concerning a nationalism-inspired Bengali public culture, which was increasingly Hindu in orientation. These discussions on translating western science, further reflected upon the biographic inclusion of a range of western terms and concepts to describe homoeopathy, and its impact on the vernacular language.

A common feature of most biographies was to glorify homoeopathy as a significant constituent of the progressive, modernising west. It was projected as an innovative and cutting -edge European science that critiqued deep-seated orthodoxy of even the western medical mainstream. Representative biographies of Hahnemann in Bengal frequently referred to homoeopathy's advent as the 'most glorious and beneficent reform' 117 that would 'overturn the whole of the present practice of medicine'. ${ }^{118}$ Echoing a common

\footnotetext{
${ }^{110}$ See Gyan Prakash (1999), 'Translation and Power', Another Reason: Science and the Imagination of Modern India, (New Jersey: Princeton University Press), pp. 49-85 and idem (Autumn 1992), 'Science 'Gone Native' in Colonial India', Representations, 40, Special Issue: Seeing Science, pp. 153-178. Also see Pratik Chakrabarti (2006), Western Science in Modern India: Metropolitan Methods, Colonial Practices, (Delhi: Permanent Black).

${ }^{111}$ Shruti Kapila (2010), 'The Enchantment of Science in India', Isis, 101, 1,pp. 120-132

${ }^{112}$ See Michael Dodson (2005), 'Translating Science, Translating Empire: The Power of Language in Colonial North India', Comparative Studies in Society and History, 47, 4, pp. 809-835 and Marwa Elshakry (2013), Reading Darwin in Arabic,, 1860-1950, (Chicago: University of Chicago Press)

${ }^{113}$ See K. Chatterjee (1925), 'Bharate Krama Samasya' (Problem of Dosage in India), Hahnemann, 8, 8, pp. 405-407

${ }^{114}$ Ibid.

115 Ibid.

${ }^{116}$ Ibid

${ }^{117}$ Mahendralal Sircar (May 1887), 'Hahnemann and His Work', Calcutta Journal of Medicine, 12, 10, pp. 391416

${ }^{118}$ F.C. Skipwith (1852), 'Homoeopathy and Its Introduction into India', Calcutta Review, 17, p. 19
} 
language of radicalism, unorthodoxy, western rationalism and reform, homoeopathy was, to a certain extent, mapped onto extant western inspired reformist discourses like that of Brahmoism in Bengal that had set out to modernise Hinduism as a rational, religion in the light of western Unitarianism. ${ }^{119}$ Indeed, in highlighting Brahmoism as a 'rational, scientific reformist agenda against orthodoxy and irrationality', the biographies indicated a close resonance between the visions of homoeopathy and Brahmoism. At one level, men like Mahendralal Sircar were reported as champions to the cause of Brahmo reform. It was noted that

Dr Sircar hated from the bottom of his heart all retrogressive movements. He publicly taunted those educated men who advocated progress in science, literature and politics but propounded retrogressive views in matters of social life. His sympathy for the great reformer Raja Rammohan Roy, were due to the fact of his having inaugurated religious and social reforms. ${ }^{120}$

An obituary collection of Mahendralal explicitly stated his appreciation of the Brahmo cause- including his material help in the foundation of the Bharatbarshiyo Brahmo Mandir. ${ }^{121}$ Mahendralal, however, was not alone. Biographies of most renowned homeopaths included appreciative discussions of Brahmo activities as 'rational'. Some like those of Pratap Chandra Majumdar and his associates including M.M.Basu and Akshay Kumar Dutta were introduced as practicing Brahmos. Simultaneously, the biographies were meticulous in narrating the profound interests of the contemporary Brahmo leaders towards the German doctrine. Biographies of Pratap Chandra Majumdar in particular detailed the abiding faith of the Tagore family in homoeopathic cure as an acceptable import from the west. ${ }^{122}$ Biographies of the physician detailed that after an instance of easy recovery from serious illness, Debendranath Tagore declared his unbound faith in homoeopathy as opposed to allopathy that engaged in 'mere patchwork' in the body. Homoeopathy, for him, was the marker of a more rational, holistic therapeutic. ${ }^{123}$ Rabindranath himself, it has been suggested, marvelled at the doctrine. Biographies of Pratap Chandra Majumdar sketched Rabindranath's efforts towards establishing a charitable dispensary in his zamindari estate of Silaidaha to promote free distribution of homoeopathic drugs. ${ }^{124}$ The western, unorthodox aspect of homoeopathy was repeatedly played up through similar discussions. Thus Vidyasagar, another preeminent reformist and promoter of homoeopathy, was recorded as having built up an enviable private collection by importing relevant homoeopathic books from Europe. ${ }^{125}$ The progressive, cheap emancipating doctrine was described as gaining fast foothold across the colonial world. It was carefully noted that, 'wherever ships go, there is spreading the knowledge of this doctrine and practice. From Rio Janeiro comes proof of

\footnotetext{
119 For a standard study of Brahmoism as a west inspired reform agenda in search of a modern, rational religion see David Kopf (1979), The Brahmo Samaj and the Shaping of the Modern Indian Mind, (New Jersey: Princeton University Press)

120 Quoted in Sivanath Shastri, Men I Have Seen, in Atmacharit (My Life), pp. 506-507

${ }^{121}$ Amritalal Sircar (1905), Obituary Notice of Mahendralal Sircar CIE, MD, DL, (Calcutta: Anglo Sanskrit Press), pp. 30-33. See especially 'Dr Sircar and Hindu Orthodoxy’, p. 49

122 J.N.Majumdar (1940), 'Dr. Pratap Chandra Majumdar M.D', Hahnemann, 23, 6, pp.322-324

${ }^{123}$ Ibid, pp. 323-324.

${ }^{124}$ Ibid, p. 323.

125 Jitendranath Majumdar (1940), 'Dr. Pratap Chandra Majumdar M.D’, Hahnemann, 23, 5, pp. 261-262
} 
its extension, from Labuan and the Spice Isles, from India, New Zealand and Australia, from the steppes of Tartary and from the coast of Africa... ${ }^{126}$

Yet, while highlighting the western, rational, radical, reformist core of the doctrine, the biographies were meticulous as well in discussing homoeopathy's inherent reverberation with age-old traditional spirituality of India ${ }^{127}$ Ascription of a distinct religio-spiritual identity on homoeopathy itself is evident from the frequent resort to literary idioms with underlying Hindu resonance, like 'high priest', 'Guru' or preceptor, 'sheeshya' or disciple, 'deekha' or initiation, 'bhakti' or faith , 'conversion' in depicting homoeopathic lives. Evidently propelled by the interests of medical commerce around a professedly western science, and catering to the demands of a growing print market, many of the biographies, nonetheless, were titled as 'Charitkatha'. ${ }^{128}$ It is difficult to overlook the allusion to an entire body of Hindu 'Charita' literature of the medieval and early modern times that were primarily religious and hagiographic in orientation. A profusion of titles as 'Sadhu Batakrishna Pal', 'Prabhu Hahnemann er Proti' , 'Maharshi Hahnemann' and 'Maheshchandra Charitkatha' reiterates the position that trade in the popular print market was very often 'led by, rather than leading the popular taste', ${ }^{129}$ their presentation often slanted towards appealing to a mass readership. Further, we have already explored how the depiction of individual lives of physicians were woven around the recurrent typologies of piety, service, temperance, sacrifice and charity. As the existing historiography illustrates, such ideas had begun acquiring a significant position in the Hindu nationalist lexicon since the late nineteenth century. ${ }^{130}$ Some authors made more explicit connections between Hindu pasts and homoeopathy, claiming 'homoeopathy is our own Vedic property which has recently come back to us dressed in western attire. If we make it our own, with time it will be most efficient in maintaining the power, health and resources of independent 'swaraj' India.' ${ }^{131}$ Often expressed through English language texts, such processes of translation and vernacularisations of homoeopathy illustrate that the 'vernacular' is more about the 'style and sensibility they stood for', rather than any particular language.

Indeed, the fractured, hybrid, ambiguous identity of homoeopathy is captured most convincingly in the many lives of Hahnemann circulating in Bengali print since the 1860s. Biographies of Friedrich Christian Samuel Hahnemann collectively appropriated the distant figure of a German physician as that one, central 'original' figure around which Bengali homoeopaths came together as a distinct community. On the one hand, the vernacular lives of Hahnemann echoed the late nineteenth- early twentieth century western, heterodox discourse around the advanced nature of homoeopathic knowledge. Hahnemann, accordingly, was highlighted as a rational scientist and a critical scholar. Widely read and knowledgeable, he

\footnotetext{
${ }^{126}$ F.C. Skipwith, 'Homoeopathy and Its Introduction into India', p. 43

${ }^{127}$ Although there is an apparent contradiction in the concurrent homoeopathic self-articulations through Brahmo and Hindu rhetoric, yet, the contradiction is more a reflection of that among many Brahmo leaders themselves especially since the schism of 1866. One needs to remember the varying degrees of Hindu empathies of many Brahmo leaders of the later nineteenth century including Keshab Chandra Sen, Rajnarain Basu or even Rabindranath Tagore among others.

${ }^{128}$ See for instance see Srish Chandra Talapatra (1946), Mahesh Chandra Charitkatha (Life of Mahesh Chandra), (Calcutta: Economic Press).

${ }^{129}$ Anindita Ghosh, Power in Print, pp. 24-25

${ }^{130}$ See for instance R. Srivastan (2006), 'Concept of 'Seva' and the 'Sevak' in the Freedom Movement', Economic and Political Weekly, 41, 5, pp. 427-438 and Raminder Kaur (2003), Performative Politics and the Cultures of Hinduism: Public Uses of Religion in Western India, (London: Anthem Press), p. 157

${ }^{131}$ Kalikumar Bhattachrya (1924), ‘Ashar Alok' ('Light of Hope'), Hahnemann, 7, 2, p. 80
} 
was written about as ' $[\ldots]$ a thinker - and a very original one $[\ldots]{ }^{\prime 32}$ His logical bent of mind and his aptitude for questioning the established order of things were emphasized as markers of great intellect. ${ }^{133}$ Depicted as an quintessential scientist engaged in laborious research, it was argued that '...his discovery was not the mere theory of a chamber philosopher indulging in idle reveries, but a plain induction from facts and experiments... after a series of trials covering many years of his life. ${ }^{, 134} \mathrm{He}$ was credited with anticipating future directions in scientific research as biographers concluded that '...the Chemistry of our day is more and more approaching Hahnemann...the infinitely little is becoming infinitely potent and the bulk and energy of particles are seen to be in inverse ratio.' 135

On the other hand, an impressive array biographies approached Hahnemann through the prism of spirituality and faith. He was portrayed as a sacred, mystic persona in possession of divine powers. Quoting the Hindu text Gita, these biographies drew analogies between Hahnemann and the scriptural Divine power that was reborn periodically to restore religion on the face of the earth. ${ }^{136}$ Depicting him as a 'chosen messiah' ${ }^{137}$ it was argued that Hahnemann was sent with the preordained mission to cure millions of ailing people with his talent, sacrifice and compassion. ${ }^{138} \mathrm{He}$ was addressed with epithets like 'Sadhu' or the hermit, 'Guru', 'Maharshi' and 'Prabhu' that closely stood for 'spiritual head'. ${ }^{139}$ Other than the subtle references, there were more explicit instances of comparisons with major deities. A poem titled 'Deboddeshe' ('To the Divine'), published in the journal Hahnemann, for instance, compared Hahnemann with both Siva and Budhha. ${ }^{140}$ Hinting at Hahnemann's experiments with different drugs on himself, the poet drew analogy between him and Lord Siva, who according to Hindu mythology, had consumed poison in order to save the Gods. His determination to overcome disease and human distress was shown to be analogous with Buddha's spiritual quest towards defeating death. Analysing the dramatic effect of Hahnemann on the Bengalis, the biographies asserted that 'he has shown the path to salvation from diseases, has liberated them from fear... has transformed drugs into sweets...' ${ }^{141}$ Comparing his discovery to a holy blessing, a poem titled Hahnemann described homoeopathy's rising popularity in every household. ${ }^{142}$ Faith in homoeopathy was coupled with a deep devotion towards Hahnemann in such households. An instance of the heightened literary exposition of such emotions can be found in the drama 'Shantir Sandhan' ('In Search

132 James C Wood (December 1932), 'Value and Limitations of Homoeopathy', The Hahnemannian Gleanings, 3, p. 501

${ }^{133}$ Mahendranath Ray, Homoeopathy Abishkorta Samuel Hahnemann er Jiboni, pp. 23-24

${ }^{134}$ F.C Skipwith, 'Homoeopathy and Its Introduction into India', pp. 22-23.

${ }^{135}$ Himangshushekhar Ghosh (1940) , 'Hahnemann O Adhunik Bigyan'('Hahnemann and Modern Science'), Hahnemann, 23, 1, pp. 22-23.

136 Ibid. p. 20

${ }^{137}$ Bhupendranath Bandopadhyay (1926), 'Smriti Sabha'('Memorial Meeting'), Hahnemann, 9, 1, p. 34

138 Himangshushekhar Ghosh, 'Hahnemann O Adhunik Bigyan', p. 20

139 The journal Hahnemann for instance, published a series of poems on Hahnemann in its different issues across 1925, which were titled variously as, 'Prabhu Hahnemann er Proti', 'Guru Hahnemann er Proti', 'Maharshi Hahnemann er Proti' etc. For instance, see, Kalikumar Bhattacharya (1925), 'Prabhu Hahnemann er Proti' (To Hahnemann the Divine'), Hahnemann, 8, 5, p. 1

${ }^{140}$ Radharaman Biswas (1940), 'Deboddeshe' (To the Almighty), Hahnemann, 23, 1, p.19

${ }^{141}$ Anonymous (1927), 'Presidential Address at the Annual Meeting of the Midnapore Hahnemann Association’, Hahnemann, 10, 2, pp.65-66.

${ }^{142}$ Saratchandra Ghosh (1939), 'Hahnemann', Hahnemann, 22, 1, p. 1. 
of Peace') published in the journal Homoeopathy Paricharak. ${ }^{143}$ It captured a scene where the hero, a homoeopathic physician, literally worshipped the image of Hahnemann with appropriate Hindu rituals. When confronted by his wife, the physician justified his act enumerating the spiritually transformative influence on his being caused by an exposure to Hahnemann's principles.

Finally, revealing a simultaneous sense of uneasiness about the cultural impact of homoeopathy on the Bengali language, these texts contribute to the historiography assessing the translatability of science across cultures that focuses on asymmetries in language and power. ${ }^{144}$ A discreet nationalist sensibility and awareness of imbalances in power is apparent in the running concern for a probable corrupting influence on language. While recognising an ascendancy of homoeopathic texts, mostly in the form of biographies, in the vernacular print market, they discussed and debated the incorporation of a range of English (often with supposedly German roots) words and terms into the Bengali vocabulary including 'homoeopathy', 'Organon', 'vital force', 'Hahnemann', 'drug-proving', 'potency', 'infinitesimal dose', 'chronic-disease', 'law of similars' and the like. To some, such overabundance of scientific writing itself had a distinctly positive impact on the language as a whole in expanding its scope ${ }^{145}$ For others, a prose littered with a profusion of foreign words was detrimental to the healthy growth of the vernacular languages. In their confusion over whether to incorporate the foreign terms as they were, or to find their vernacular equivalents, these texts reflected the popular version of similar anxieties that had been perturbing the official circles in previous decades. ${ }^{146}$ The journal Hahnemann ${ }^{147}$ edited by Basanta Kumar Dutta that published a number of biographies also publicised a series of articles titled 'Homoeopathic Bangla Sahitya' ('Homoeopathic Bengali Literature') echoing these concerns. The author expressed sincere reservations against the arbitrary ways in which the bulk of the homoeopathic concepts were being translated in the biographies and beyond. ${ }^{148}$ Lamenting the lack of any coherence or standardisation in the various acts of adoption and translations, he pointed out that it was quite common for authors to use different Bengali words for a single English term that was hardly helpful for the readers. ${ }^{149}$ Such writings were considered deeply injurious for the cause of both homoeopathy and Bengali as a language. ${ }^{150}$ To him, efforts at scientific translations, however necessary, ran the tragic consequence of generating a prose that was Bengali only in its form and alphabets. Such recurrent angst about the purity of language coupled with the deliberate depiction of homoeopathic lives within (Hindu) nationalist tropes reiterate 'translation' itself as deeply constitutive process that shaped colonial medicine.

\footnotetext{
143 Ajit Shankar De (April 1928), 'Shantir Shandhan' (In Search of Peace), Homoeopathy Pracharak, 2, 1, pp. $42-45$

${ }^{144}$ Michael Dodson, 'Translating Science, Translating Empire' pp. 809-835

${ }^{145}$ Basanta Datta (ed.) (March 1876), 'Review by Samaj Darpan', Datta's Homoeopathy Series in Bengalee, 3 , promotional advertisement at the end.
}

\footnotetext{
${ }^{146}$ For discussions on colonial administrative efforts at translation of western knowledge for pedagogic purposes see Ishita Pande (2010), Medicine, Race and Liberalism in British Bengal: Symptoms of Empire, (London and New York: Routledge), pp. 77-82 and Michael Dodson, 'Translating Science, Translating Empire' pp. 809-835 ${ }^{147}$ It should be noted that Hahnemann was the name of a number of journals circulating in Bengal since the late nineteenth century. Hahnemann edited by Basanta Kumar Datta was different from Hahnemann published by the Hahnemann Publishing Company of the Bhars.

148 Basanta Kumar Datta (1884), 'Homoeopathic Bangla Sahitya'('Homoeopathic Bengali Literature'), Hahnemann, 2, 12, p. 222

149 Basanta Kumar Datta (1884), 'Homoeopathic Bangla Sahitya'('Homoeopathic Bengali Literature'), Hahnemann, 2, 10, p. 183

150 ibid.
} 


\section{Conclusion}

In our exploration of the writing and publication of an extensive repertoire of biographies around physicians practicing homoeopathy in Bengal, we have refrained from using biographies merely as sources for other kinds of histories. Nor has the article attempted a biographic endeavour around any individual life. Rather, we have analysed the relevance of the genre of biography in relation to the colonial trajectories of a western heterodox medicine. Even as the historiography studying the "new geographies of nineteenth century science and medicine' is expanding to explore various facets of the profusion of print culture around science, popular medico-scientific biographies as a site has hardly been explored, especially in South Asia. ${ }^{151}$ Through an exploration of the myriad kinds of medical lives, this paper has reiterated biography's vision in significant democratisation of science and medicine. Posing as contextual, even complementary text to actual works of science or medicine, the biographies upheld a certain egalitarian promise of a 'republic of science' reaching out even to the functionally literate. But the chimera of any democratic, universal concept of science somewhat dissolves as one unravels biography's role in the translation and cultural reconstitution of science across contexts. Indeed, lives of colonial 'men of science' can hardly be narrated without reference to local issues of power, language, identity and nationalism. While this is not entirely novel to the existing scholarship on postcolonial science, yet, the ambiguous refiguring of homoeopathy as a Hindu national science of western origin further illustrate that the apparent 'displacements' and 'enchantments' of colonial science were in many cases self-conscious, deliberate and deeply entwined with the dynamics, conventions and interests particularly of medical commerce and popular print market.

Perhaps the larger point that the paper has driven home, is the relationship between the life stories and practices marginalised by the state or scientific authorities. In the absence of any substantial state records on homoeopathy's history in British India, this article identifies the systematic publication of biographies as a significant arena of assertion for a heterodox, family-based, practice like homoeopathy. In so doing, it offers a glimpse into the complex relationship between texts, society and the practices actively censured by the state that are often caught up within family, caste, kinship or sacred networks. Following Arjun Appadurai, the essay has identified homoeopathic biographies, as useful reminders of the possibility of 'creation of documents and their aggregation into archives ... outside the purview of the state'. ${ }^{152}$ It is useful to remind ourselves that the very survival and availability of these plethora of texts, mostly in their now-obscure-yet-still-continuing entrepreneurial concerns, signify the power of such alternative archives as 'an aspiration rather than a mere recollection' ${ }^{\text {'53 }}$ - as the 'material site of a collective will to remember.' 154

Such traces of the resilience of unorthodox, marginalised practices also caution us against concluding any straightforward narrative of victimhood around these practices. We have been aware of their role in the 'domains of politics and profiteering' by underlining the role of the homoeopathic family-firms with relation to the biographies. In contending

\footnotetext{
${ }^{151}$ Although there has been some critical explorations in science biographies in the anglo-american academy, yet, in a recent anthologies on new sites to study science Bernard Lightman urges for a more serious engagement with science biographies. See Bernard Lightman and Aileen Fyfe (ed.) (2007), Science in the Marketplace: Nineteenth Century Sites and Experiences, (Chicago: University of Chicago Press), p.14 ${ }^{152}$ Arjun Appadurai (2003), 'Archive and Aspiration' in Joke Brouwer and Arjen Mulder (ed.), Information is Alive, (Rotterdam: V2_Publishing/NAI Publishers), p. 16.

${ }^{153}$ Ibid, p. 16

${ }^{154}$ Ibid, p. 17
} 
biographies to be as much the story of the subjects as of the biographers and publishers themselves, the paper has unravelled the intertwined trajectories of commerce, print capital, nationalist ideology and medical knowledge with relation to homoeopathy in Bengal. Indeed, the nexus between leading Calcutta-based commercial families and biographies often entailed its own sets of exclusions and violence regarding what constituted 'authentic' medical knowledge. The mofussil as a space, for instance, was a frequent target of the biographies as they expressed recurrent anxieties about the possible, inevitable distortions inflicted on pristine science beyond the urban enclave of Calcutta. Distinguishing between the urban and sub-urban practitioners of homoeopathy it was feared that 'the standard, good quality texts and physicians are never adequately appreciated beyond the capital (i.e. Calcutta), as beyond it homoeopathy is practiced variously.' 155

Further, the network between the leading homoeopathic families, commerce and life stories is instructive of the nature and relevance of 'biography' itself as a literary genre that was indulged in by sections of the educated bhadralok. A pervading concern in the scholarship on life histories in South Asia has been to analyse the kind of selfhood and individualism refracted through these texts. ${ }^{156}$ Scholars have tried to assess if the sense of selfhood, of personal identity and agency, is muted and subsumed within larger social and cultural domains. A related interest has been to search for the 'interiorised private self' as a signifier for a modern bourgeois identity. ${ }^{157}$ So what can be concluded of the selves captured in this distinct corpus of medico-scientific biographies? The contours of an autonomous individual self was most evidently blurred in the context of the homoeopathic lives, insofar as there were persistent invocations of similar other lives within a single text. The readers were often reminded of the futility of reading these lives in isolation. Thus, a biography of Rajendralal Dutta stated, 'as the works of Rajendra Dutt as a healer were so inseparably connected with those of the late Dr Mahendralal Sircar, it would not I hope tire the patience of our audience if I would relate how Dr Sircar's conversion was brought about.' ${ }^{158}$ Framed not within any explicit singular network of caste or kinship, these lives were, nonetheless, written and studied within a carefully cultivated sense of a collective around the leading homoeopathic families as well as (Hindu) nationalistic sensibility. They exemplify the processes of construal of communities with intersecting ideologies of religion, family, or kinship to sustain apparently modern, secular, scientific doctrines claiming western origin. The emplacement of the biographic individuals within a shared sense of community is palpable as the subjects were variously referred to as the 'leader of the movement', 'conversion' narratives were glorified, while the death of some were lamented as a 'loss for the spiritual mission of homeopathy'. Such creation of communitarian aspiration was evident when biographies were suggestively titled as accounts of the 'first homoeopathic missionary in India' and frequent appeal was sent out for 'more diligent workers' and those 'devoted to the cause of homoeopathy.' Moreover, the bourgeois distinctions between any defined sense of 'private' and 'public' too stands problematized in these texts, as the rhetoric of family as well as the perceived familial emotions of intimacy, affect, paternal love and the like were transposed onto the public domains of enterprise and medical culture. Virtually nothing was conveyed of the emotional-psychological-sexual tensions of these protagonists beyond their

\footnotetext{
155 Basanta Kumar Datta (1884), 'Homoeopathic Bangla Sahitya' (Homoeopathic Bengali Literature), Hahnemann, 2, 10, p. 182

${ }^{156}$ For a substantive discussion of these questions in relation to the entire corpus of life histories in South Asia see David Arnold and Stuart Blackburn (ed), Telling Lives in India, pp. 2-3, 19-22

${ }^{157}$ Sudipta Kaviraj (2004), 'The Invention of Private Life: A reading of Shibnath Shastri’s Autobiography', in David Arnold and Stuart Blackburn (ed.) Telling Lives in India : Biography, Autobiography and Life History, (Bloomington: Indiana University Press), pp. 83-115. Also see, Mattison Mines (1994), Public Faces, Private Voices: Community and Individuality in South India, (Berkley: University of California Press).

158 S.C.Ghose, 'Homoeopathy and Its First Missionary in India', p. 341
} 
professional lives. In their defiance to conform to any exalted, western ideal of narrating an autonomous modern self, the homoeopathic biographies were not only in conversation with other colonial life histories, but homoeopathy itself was made into a uniquely colonial modern experience.

Finally, through the late nineteenth-early twentieth century there were extensive deliberations on the status of biography in recovering and recording the past. Acclaimed as a useful form of literary exercise that the colonial societies ought to nurture, biography was widely recognised as one of the most effective forms of writing history. Participating actively in the 'enormous public enthusiasm for history', the physician-biographers, nonetheless, posed a critique to the emerging western rationalist-positivist notion of 'scientific' history. Asserting biography-writing and history-writing as analogous processes, these authors registered their emphatic differences with regards to the plausibility of narrating any objective biographic pasts. 